\title{
Transcriptomic Analysis of Sinorhizobium meliloti and Medicago truncatula Symbiosis Using Nitrogen Fixation-Deficient Nodules
}

\author{
Claus Lang and Sharon R. Long \\ Department of Biology, Stanford University, Stanford, CA 94305-5020, U.S.A.
}

Submitted 5 January 2015. Accepted 30 March 2015.

\begin{abstract}
The bacterium Sinorhizobium meliloti interacts symbiotically with legume plant hosts such as Medicago truncatula to form nitrogen-fixing root nodules. During symbiosis, plant and bacterial cells differentiate in a coordinated manner, resulting in specialized plant cells that contain nitrogen-fixing bacteroids. Both plant and bacterial genes are required at each developmental stage of symbiosis. We analyzed gene expression in nodules formed by wild-type bacteria on six plant mutants with defects in nitrogen fixation. We observed differential expression of $482 \mathrm{~S}$. meliloti genes with functions in cell envelope homeostasis, cell division, stress response, energy metabolism, and nitrogen fixation. We simultaneously analyzed gene expression in M. truncatula and observed differential regulation of host processes that may trigger bacteroid differentiation and control bacterial infection. Our analyses of developmentally arrested plant mutants indicate that plants use distinct means to control bacterial infection during early and late symbiotic stages.
\end{abstract}

Nitrogen fixation by rhizobial bacteria in symbiosis with legumes is an important component of the global nitrogen cycle (Vance 2001). Rhizobium-legume symbioses involve the formation of specialized plant organs called root nodules, in which bacteria receive plant-derived carbohydrates in exchange for reducing dinitrogen to plant-usable ammonia. Nodulation is initiated when plant root compounds such as flavonoids trigger production of a bacterial signal, Nod factor. Perception of this lipochitooligosaccharide by specific plant receptors alters root hair growth and stimulates dedifferentiation of cortical root cells to establish the nodule primordium (Xiao et al. 2014). Bacteria invade the developing nodule via plant-produced infection threads. Invasion requires live bacterial cells that produce one or more extracellular polysaccharides (EPS), such as succinoglycan (EPS-I) or galactoglucan (EPS-II) (Cheng and Walker 1998; Pellock et al. 2000). At the tips of infection threads, bacteria are ultimately released into invasion-competent host cells by an endocytosislike mechanism to form organelle-like structures called symbiosomes. In $M$. truncatula and some other legumes, host cells

Nucleotide sequence data is available in the National Center for Biotechnology Information Gene Expression Omnibus database under accession number GSE53705.

Corresponding author: S. R. Long; Telephone: +1.650 .723 .3153 ; Fax: +1.650.725.8309; E-mail: srl@ stanford.edu

*The $\boldsymbol{e}$-Xtra logo stands for "electronic extra" and indicates that one supplementary figure and eleven supplementary tables are published online.

(c) 2015 The American Phytopathological Society and bacteria within symbiosomes undergo a differentiation process involving genome endoreduplication and morphological changes (Kondorosi et al. 2013). Nitrogen fixation is carried out by endosymbiotic bacteroids, not by free-living cells.

$M$. truncatula produces indeterminate nodules with a distal tip meristem. Continuous division of plant meristem cells, infection, and differentiation result in a spatial zonation of developmental stages within the nodule organ along a distal to proximal axis. Based on plant cell morphology, five zones can be distinguished in Medicago nodules (Fig. 1A): the meristematic zone I; infection zone II; interzone II-III; nitrogen-fixation zone III; and senescence zone IV (Vasse et al. 1990). Each zone contains characteristic bacterial developmental stages, ranging from free-living-like bacteria within infection threads in the infection zone to elongated, Y-shaped bacteroids (type 4) in the nitrogen-fixation zone and senescing bacteroids (type 5) in the senescence zone (Fig. 1A) (Vasse et al. 1990).

Genome-wide transcription profiling can identify symbiotically regulated plant and bacterial genes. Initial comparisons of free-living bacteria to whole root nodules revealed that the expression levels of 10 to $20 \%$ of all S. meliloti genes change during symbiosis (Barnett et al. 2004; Becker et al. 2004; Capela et al. 2006). Several different approaches have been used to study transcriptomic changes during nodule development. Nodulation time-course experiments were carried out to identify early and late symbiosis genes in S. meliloti (Capela et al. 2006) and M. truncatula (Maunoury et al. 2010). More recently, lasercapture microdissection (LCM) has been used to study plant (Limpens et al. 2013; Roux et al. 2014) and bacterial (Roux et al. 2014) gene expression in different nodule zones. In addition, LCM was used to compare $M$. truncatula gene expression during rhizobial and root knot-nematode infection (Damiani et al. 2012). Bacterial mutants have been used to characterize bacterial symbiotic regulators (Barnett et al. 2004; Bobik et al. 2006; Capela et al. 2006), and several M. truncatula and S. meliloti symbiosis mutants have been used to characterize plant gene expression changes during early symbiotic stages (Maunoury et al. 2010; Mitra et al. 2004; Moreau et al. 2011). To date, plant mutants have not been used for genome-wide studies of bacterial gene expression during nodule development.

Plant mutants that develop nodules and support bacterial infection but are defective in nitrogen-fixation $(d n f)$ mutants may be particularly useful to study bacterial gene expression at intermediate and late symbiotic stages (Starker et al. 2006). In previous studies on seven plant mutants, expression assays of the nitrogenase gene nifH revealed that mutants $d n f 4$ and $d n f 7$ are blocked at an earlier symbiotic stage than $d n f 3$ and $d n f 6$ but at a later stage than $d n f 1, d n f 2$, and $d n f 5$ (Starker et al. 2006). $d n f l$ is deficient in one component of a nodule-specific signal 
peptidase complex of the secretory pathway that is required for the targeting of nodule-specific cysteine-rich (NCR) peptides (Wang et al. 2010). NCR peptides, encoded by a family of approximately 600 genes, are implicated in terminal bacteroid differentiation, as bacteria fail to differentiate into nitrogenfixing bacteroids in $d n f 1$ plants (Van de Velde et al. 2010). $d n f 2$ is deficient in a putative phosphatidylinositol-specific phospholipase $\mathrm{C}$; bacteria are released from infection threads in dnf2 plants, but fail to differentiate further (Bourcy et al. 2013; D. Wang and S. R. Long, unpublished). Genetic and functional characterization of other $d n f$ mutants is ongoing.

In this study, we used Affymetrix GeneChips containing probe sets for both $S$. meliloti and $M$. truncatula genes (Barnett et al. 2004) to analyze global gene expression of both organisms in developmentally arrested root nodules from six $d n f$ plant mutants. By using plant mutants arrested at different developmental stages and by detailed comparisons with previous $S$. meliloti microarray experiments, we identified symbiotically regulated processes in S. meliloti, placed them in the nodule developmental context, and related them to processes that take place in the plant.

\section{RESULTS AND DISCUSSION}

Bacterial gene expression differs most

from wild-type in early-arrest plant mutants.

We used plant $d n f$ mutants $(d n f 1, d n f 2, d n f 3, d n f 4, d n f 5$, $d n f 7)$ to enrich for bacterial cells arrested at different stages of

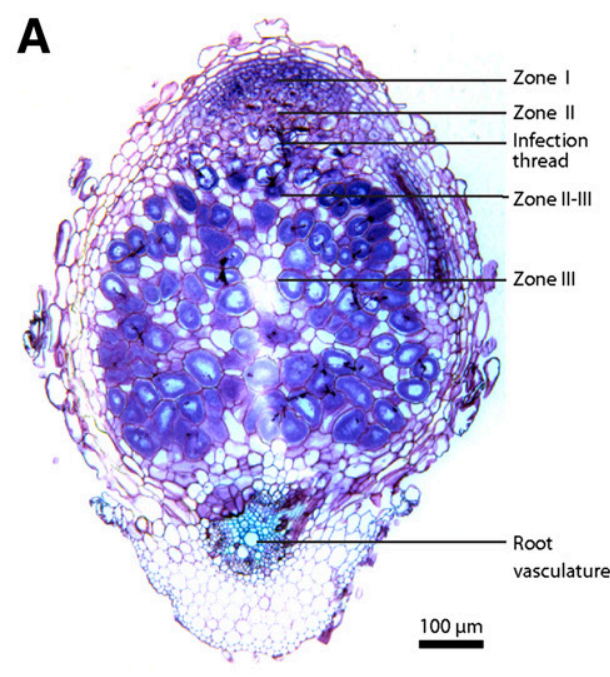

\begin{tabular}{|l|l|l|l|}
\hline $\begin{array}{l}\text { Nodule } \\
\text { zones }\end{array}$ & $\begin{array}{l}\text { Nodule zone } \\
\text { description }\end{array}$ & $\begin{array}{l}\text { Bacterial } \\
\text { differentiation } \\
\text { stage }\end{array}$ & $\begin{array}{l}\text { Characteristic features of } \\
\text { bacteria in different nodule } \\
\text { zones }\end{array}$ \\
\hline I & Meristem & & Few or no bacteria \\
\hline II & Infection zone & $\begin{array}{l}\text { Undifferentiated } \\
\text { bacteria }\end{array}$ & $\begin{array}{l}\text { Undifferentiated bacteria in } \\
\text { infection threads }\end{array}$ \\
\cline { 3 - 5 } & Type 1 bacteroids & $\begin{array}{l}\text { Freshly released from IT, } \\
\text { resemble free-living bacteria }\end{array}$ \\
\cline { 3 - 4 } & Interzone II-III & Type 3 bacteroids & $\begin{array}{l}\text { Fully elongated; heterogeneous } \\
\text { cytoplasmic electron density }\end{array}$ \\
\hline III & Nitrogen fixation & Type 4 bacteroids & $\begin{array}{l}\text { Elongated, distinct cytoplasmic } \\
\text { zones of high (ribosomes) and } \\
\text { low electron density }\end{array}$ \\
\hline IV & Senescence & Type 5 bacteroids & $\begin{array}{l}\text { Senescing bacteroids, low } \\
\text { electron density }\end{array}$ \\
\hline V & Post-senescence & $\begin{array}{l}\text { Undifferentiated } \\
\text { bacteria }\end{array}$ & $\begin{array}{l}\text { Bacteria from remaining } \\
\text { infection thread grow } \\
\text { saprophytically on senescing } \\
\text { tissue. }\end{array}$ \\
\hline
\end{tabular}

B
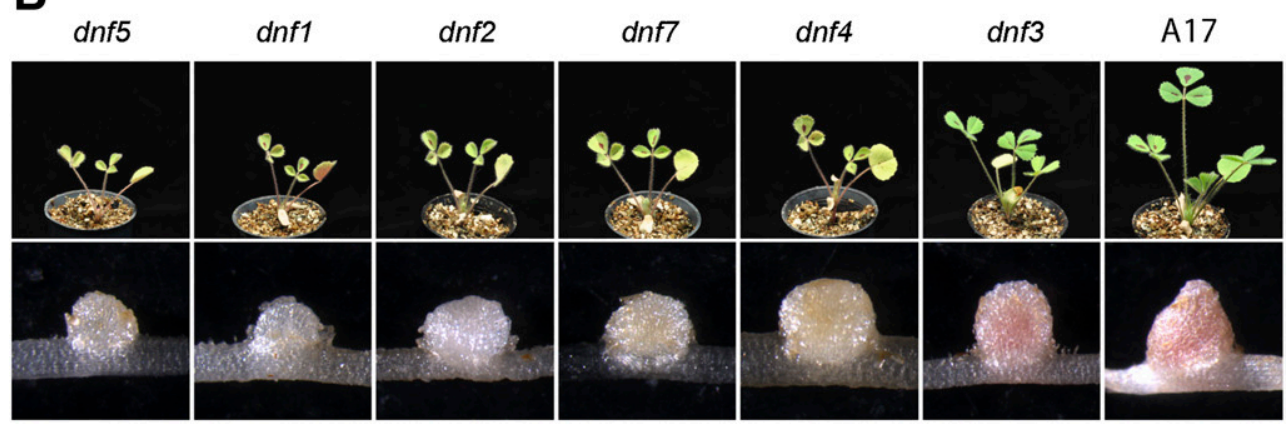

Jemalong

C

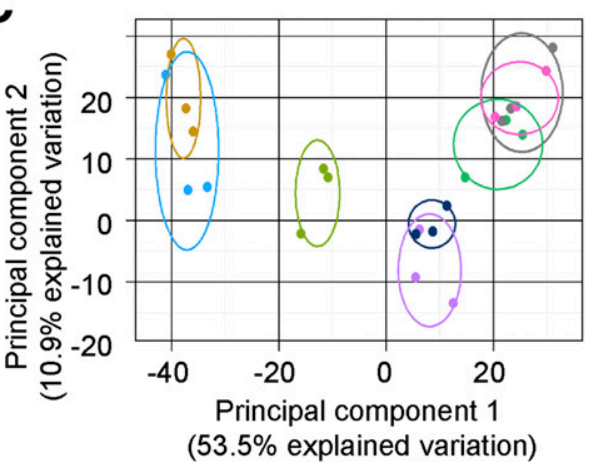

Groups

-A17

- dnf1

- dnf2

- dnf3

- dnf4

$\rightarrow$ dnf5

- dnf7

- Jem.

Fig. 1. Root-nodule structure and $d n f$ plant phenotypes. A, Overview of nodule zones and bacteroid differentiation stages in indeterminate nodules. The image shows a longitudinal section (10- $\mu$ m thickness) of a 21-day-old Medicago truncatula-Sinorhizobium meliloti nodule. Nodule zones I to III are indicated on the right and the corresponding bacterial differentiation stages and their characteristic features are listed in the table. The nodule was embedded in Technovit 7100 without prior fixation. Sectioning and staining was carried out as described previously (Wang et al. 2010). IT = infection thread. B, Developmentally arrested plant mutants. Images of shoots (upper row) and root nodules (lower row) of wild type (A17 and Jemalong) and $d n f$ mutants. Plants were photographed three weeks after inoculation with $S$. meliloti CL150. C, Principal component analysis of bacterial gene-expression data. The first two principal components and their contribution to the overall variability of the data (\%) are shown on the $x$ axis and on the $y$ axis. A 68\% confidence ellipse is shown for each nodule type. 
bacteroid development. Previous characterization of $d n f$ plants showed that root-nodule development is arrested at distinct stages: development in $d n f 5$ and $d n f 1$ plants is arrested earlier than in $d n f 2, d n f 7, d n f 4$, and $d n f 3$ plants (Domonkos et al. 2013; Mitra and Long 2004; Pislariu and Dickstein 2007; Starker et al. 2006; Wang, et al. 2010). In our experiments, we found that $d n f$ plants were smaller than wild-type plants at 21 days postinoculation (dpi), and leaves of mutants with an early ( $d n f 1$, $d n f 5)$ or intermediate $(d n f 2, d n f 4, d n f 7)$ arrest showed chlorosis (Fig. 1B) consistent with nitrogen limitation. Nodules of earlyand intermediate-arrest plant mutants were white and spherical, indicative of deficient function (Fig. 1B). While early-arrest mutant nodules were typically smaller than wild-type nodules, some nodules from intermediate-arrest plants were as large as those of wild-type plants. One mutant, $d n f 3$, was similar to the wild-type in both plant and nodule appearance. The hereobserved phenotype of the $d n f 3$ mutant is consistent with the original description by Starker et al. (2006). Acetylene reduction assays demonstrated that the $\operatorname{dnf} 3$ mutant, albeit phenotypically more similar to the wild-type than other $d n f$ mutants, is significantly impaired in nitrogen fixation (Starker et al. 2006). To identify genes that are regulated during bacteroid differentiation, we harvested nodules from roots of six $d n f$ mutants and two wild-type plant lines and defined their transcription profiles. Principal component analysis (PCA) of bacterial gene expression profiles in the different lines (Fig. 1C) is consistent with inference from morphology, i.e., bacterial gene expression profiles of the early-arrest mutants $d n f l$ and dnf5 are most different from wild-type and fairly similar to each other. Bacterial expression profiles of nodules from intermediatearrest plants $d n f 2, d n f 4$, and $d n f 7$ are closer to that of wild type. Among these, we noted that $d n f 4$ and $d n f 7$ profiles are similar to each other but the $d n f 2$ nodule profiles are distinct. The expression profiles of $d n f 3$ nodules are most similar to wild-type.

Another comparison metric is differential expression of bacterial genes in $d n f$ mutants versus Jemalong wild type. We identified 482 differentially expressed genes (significance criteria: adjusted $P$ value $<0.05$, fold change $>2$ ) (Supplementary Table S1). Most differential changes in comparison with wild type were identified in $d n f 1$ and $d n f 5$ nodules, followed by $d n f 2$, $d n f 7$, and $d n f 4$ nodules (Fig. 2A). No significant bacterial gene expression differences were found when $\operatorname{dnf3}$ and A17 nodules were compared with Jemalong nodules. Overall, these pairwise comparisons and the PCA show that our $d n f$ nodule analysis resolves four developmental stages of bacteroid development. The earliest developmental stage is represented by $d n f 1$ and $d n f 5$ nodules. Development of $d n f 2$ nodules is arrested slightly later then $\operatorname{dnf} 1$ and $\operatorname{dnf} 5$ but distinctly before the intermediate-arrest nodules $d n f 4$ and $d n f 7$. The $d n f 3$ mutant is arrested later than the other $d n f$ mutants, and we do not detect significant changes in bacterial gene expression in comparison with wild-type nodules.

We derived six main clusters of bacterial genes based on hierarchical clustering of differential expression patterns (Fig. 2B and C; Table 1; Supplementary Table S2). The largest cluster, SmA, consists of 197 genes expressed at higher levels both in early- and intermediate-arrest nodules than in $d n f 3$ or wild-type nodules. The second largest cluster, SmE, consists of 122 genes that are expressed at lower levels in early- and intermediatearrest nodules than in wild-type. Cluster SmF consists of 102 genes that display lower expression levels in early-arrest nodules but are closer to normal in intermediate-stage lines. The other clusters are fairly small, totaling 61 genes. Genes in clusters SmB and $\mathrm{SmD}$ are expressed at reduced levels in most mutants but are expressed at wild-type levels in $d n f 1$ or $d n f 2$ nodules, respectively. The 28 genes of Cluster SmC are expressed at their highest levels in $d n f 2$ nodules.
To validate microarray results, we tested 12 genes from four different clusters by reverse transcription-quantitative polymerase chain reaction (RT-qPCR) (Fig. 3). The RT-qPCR profiles of all tested genes were in good agreement with the microarray hybridization results. For instance, RT-qPCR results confirmed that three genes from cluster SmA (rsiA1, smc00795, $s m c 00885)$ were expressed at the highest levels in early-arrest mutants. They were $>20$ times more abundant in $d n f 5$ nodules and approximately 10 times more abundant in dnfl nodules than in wild-type nodules. Similarly, RT-qPCR confirmed that the sitA gene from cluster $\mathrm{SmC}$ is expressed highly in $d n f 2$ nodules and that transcripts of genes from cluster SmE and SmF were expressed most abundantly in wild-type nodules (Fig. 3).

\section{Genes with increased expression in free-living cells in comparison with root nodules and known early symbiotic genes show increased expression in early-arrest nodules.}

Comparison of our results with previous $S$. meliloti transcriptome studies revealed that many genes that are differentially expressed in $\operatorname{dnf}$ mutant nodules were also identified during previous root-nodule gene-expression studies. Our primary tool for analysis was gene set enrichment analysis. We used Fisher's exact test to calculate if a gene set was enriched in a cluster and we used parametric gene-set enrichment analysis (PGSEA) to determine if a gene set showed increased or decreased expression in $\operatorname{dnf}$ mutant nodules in comparison with wild type. PGSEA revealed that genes previously shown to be increased in free-living cells in comparison with root nodules show higher expression levels in early- and intermediate-arrest nodules. These genes are enriched in cluster SmA (Supplementary Tables S3 and S4). Conversely, genes previously found to be increased in nodules in comparison with free-living cells (Barnett et al. 2004; Becker et al. 2004; Capela et al. 2006) were depleted from transcript populations of early- and intermediate-arrest nodules but enriched in late-arrest and wild-type nodules. These genes are significantly $(P<0.001)$ enriched in clusters $\mathrm{SmE}$ and $\mathrm{SmF}$. Comparison of the here-presented microarray data with previously published free-living and root-nodule samples (Barnett et al. 2004) by PCA also suggest that bacterial expression profiles in early-arrest $(d n f 1, d n f 5)$ and $d n f 2$ nodules are more similar to those of free-living cells, whereas the profiles of latearrest and wild-type nodules are more similar to those of previously published wild-type root-nodule samples (Supplementary Fig. S1).

PGSEA showed that genes previously shown to be expressed specifically during early symbiotic stages in a nodulation timecourse experiment (Capela et al. 2006, cluster 2) were also expressed at significantly higher levels in $d n f 1, d n f 5$, and dnf 2 nodules. These genes are also highly enriched in cluster SmA $\left(P=2 \times 10^{-15}\right)$. Moreover, genes expressed specifically at late symbiotic stages (Capela et al. 2006, clusters 3 and 4) are scarce in early-arrest and intermediatearrest mutant nodules and are enriched in clusters SmE and SmF. Thus, consistent with previous time-course experiments, many of the genes that are characteristic of early symbiotic stages are, indeed, expressed at higher levels in $d n f 1, d n f 5$, and $d n f 2$ nodules, while genes that are upregulated during bacteroid differentiation and nitrogen fixation in wild-type nodules are not as highly expressed in $d n f$ mutant nodules.

We also compared our results with an analysis of gene expression in laser-dissected root-nodule zones (Roux et al. 2014). Zone analysis provided information on development and differentiation, since Medicago nodules are organized in structurally distinct tissue zones that represent the various 
stages of bacterial and plant differentiation. We find that genes highly expressed in the infection zone (Roux et al. 2014, clusters 3, 4 and 5) are enriched in cluster SmA and are expressed at significantly higher levels in $d n f 1, d n f 5, d n f 2, d n f 4$, and $d n f 7$ nodules than in wild-type nodules. Genes highly expressed in the infection zone (Roux et al. 2014, clusters 3, 4 and 5) display the highest expression levels in $\operatorname{dnfl}$ and $d n f 5$, followed by $d n f 2$, and then, by $d n f 4$ and $d n f 7$ nodules. Since most bacteria in the infection zone are localized in infection threads or have just been released into plant cells, our data indicate that $d n f 1$ and $d n f 5$ nodules are highly enriched for infection thread bacteria. Nodules from $d n f 2, d n f 4$, and $d n f 7$ nodules also contain a higher proportion of infection thread bacteria than wild-type nodules, but the differences are not as strong, indicating that at least some bacteria in $d n f 2$ and a higher proportion in $d n f 4$ and $d n f 7$ nodules start to differentiate into bacteroids.

Genes expressed in the interzone II-III and in the nitrogenfixation zone (Roux et al. 2014, cluster 6) are most highly enriched in cluster $\operatorname{SmF}\left(P=2.66 \times 10^{-42}\right)$, and genes specifically expressed in the nitrogen-fixation zone are most highly enriched in cluster $\operatorname{SmE}\left(P=2.60 \times 10^{-20}\right)$.

A small cluster, SmC, contains genes that are most highly expressed in $d n f 2$ nodules and includes 15 genes previously found to be expressed in interzone II-III and in the proximal infection zone (Roux et al. 2014, clusters 9 and 11). Since this is the region in which bacteria differentiate into bacteroids, we believe that $d n f 2$ nodules are enriched for differentiating bacteroids and that genes in cluster SmC are expressed during bacteroid differentiation. The $28 \mathrm{SmC}$ cluster genes include four tRNA genes, a sitABCD-encoded manganese transport system, and five protease genes $(\operatorname{clpP} 1, \operatorname{clpS} 1, \operatorname{clpX}, \operatorname{deg} P 1$, $f t s H)$. The sitABCD manganese transport system is required for protection against oxidative stress and for symbiosis (Davies and Walker 2007). Strong expression of sitABCD in $d n f 2$ nodules implies that bacteria also encounter oxidative stress after being released from infection threads into plant host cells, consistent with observations that reactive oxygen species (ROS) are prominent in the plant environment (Cárdenas et al. 2008; Jamet et al. 2007). The role of the protease genes is not known; it is possible that they are involved in defense against nodule-specific plant-derived antimicrobial peptides that trigger bacteroid differentiation or their prominence may reflect extensive protein turnover associated with cellular remodeling. Thus functional tests of protease and other genes in cluster SmC may reveal whether they play a role in early bacteroid differentiation.

\section{Nitrogen-fixation genes are expressed in intermediate- arrest nodules but not in early-arrest nodules.}

A signature feature in $\mathrm{N}_{2}$-fixing bacteria is expression of nitrogenase (nif) structural genes. In Sinorhizobium spp., nif gene expression is regulated by the FixL/J-oxygen sensing system and the NifA transcriptional activator under microoxic conditions (David et al. 1988; Soupène et al. 1995). The FixL/J two-component system also regulates expression of the fix genes required for microoxic respiration and other functions (Batut et al. 1989; Bobik et al. 2006). We saw significant changes in expression in 28 of the 41 nif and fix genes during nodule development; 27 of the 28 genes fell into cluster SmF. Their expression profiles (Fig. 4A) show that most nif and fix genes (34 of 41) are highly expressed in wild type, $\operatorname{dnf} 3$, dnf4, and $d n f 7$ nodules, but have medium levels in $d n f 2$ and low levels in $d n f 1$ and $d n f 5$ nodules. The only exceptions are six colocalized chromosomal genes (fixI2, fixN3, fixO3, fixP3, fixQ3, fixS2) (Fig. 4A), which did not match our criteria for differential expression and are probably not strongly regulated during symbiosis. Cluster $\mathrm{SmF}$ also contains several ferredoxins $(f d x, f d x N, f d x B$, mocE, $m o c F)$ and iron-sulfur cluster assembly proteins (nifS, sufA, sufD) that are probably involved in building the nitrogen-fixation apparatus. Expression of nif and fix genes in intermediate- and late-arrest and wild-type nodules indicates that the FixJ/FixL two component system is activated. By inference, bacteria are exposed to microoxic conditions. Functional enrichment and gen-set enrichment analyses are consistent with this conclusion. Genes that were upregulated under microoxic conditions and genes that were upregulated in nodules in a fixJ-or nifA-dependent manner at 14 days after inoculation (Bobik et al. 2006) were, likewise, typically expressed at lower levels in $d n f 1, d n f 5$, and $d n 2$ versus wild-type nodules and were significantly enriched in cluster SmF.

\section{Sinorhizobium cell biology and physiology during symbiotic transitions.}

While nitrogen-fixation regulation is a well-studied aspect of Sinorhizobium differentiation, other critical aspects of cell function are not as well understood. We assigned genes to functional classes according to Riley (1993; Serres and Riley 2000) as a way of exploring how these correspond to bacterial fates during normal versus mutant symbiosis development. As expected and consistent with the analysis above, we found that the functional class of nitrogenfixation genes was among the groups with the lowest expression in early-arrest nodules in comparison with wild-type nodules.

Cell-division genes are expressed at significantly higher levels in early-arrest nodules (Supplementary Table S5). This group prominently includes genes with a binding motif for the cell cycle regulator CtrA (De Nisco et al. 2014) (Fig. 4B), and genes that are strongly expressed during G1 (De Nisco et al. 2014 , cluster 1 ) or $\mathrm{G} 2 / \mathrm{M}$ phases of the cell cycle (De Nisco et al. 2014, cluster 5). By these criteria, we infer that the plant gene products corresponding to $d n f 1$ and $d n f 5$ are required for the transition of bacteria from active division to a state in which they remain in S phase, undergoing multiple rounds of endoreduplication without division (Mergaert et al. 2006). These transcription results are consistent with the microscopic observation that bacteria in $d n f 1$ and $d n f 5$ nodules do not display the characteristic elongated bacteroid shape but resemble freeliving rod-shaped cells (Domonkos et al. 2013; Wang et al. 2010).

The cell surface is a crucially important interface for plant interaction with the bacterium (Downie 2010; Gibson et al. 2008; Jones et al. 2007). It has been shown that the lipopolysaccharide structure differs between free-living and nodule bacteria (Kannenberg and Carlson 2001), but most cellenvelope functions have not been studied in invading rhizobia. Our data show that genes for structural functions such as cell envelope, outer membrane, cell exterior, and cell surface polysaccharides are expressed at higher levels in early-arrest nodules than in wild-type nodules. This implies that bacterial cell surface architecture changes between infection and bacteroid differentiation.

We explicitly looked at previously identified regulators of ESP, outer membrane proteins and exported polysaccharides. For instance, the FeuP/Q two-component system induces the production of cyclic $\beta$-glucans in response to low osmolarity and is essential for symbiosis (Griffitts et al. 2008). FeuP itself and 11 of the 14 known FeuP-induced genes are found in cluster SmA. In addition, PGSEA showed that FeuP-induced genes are expressed at significantly higher levels in $d n f 1, d n f 2$, and $d n f 5$ nodules than in wild-type nodules. Considering that a feuP mutant is unable to form infection threads (Griffitts et al. 2008), 
A

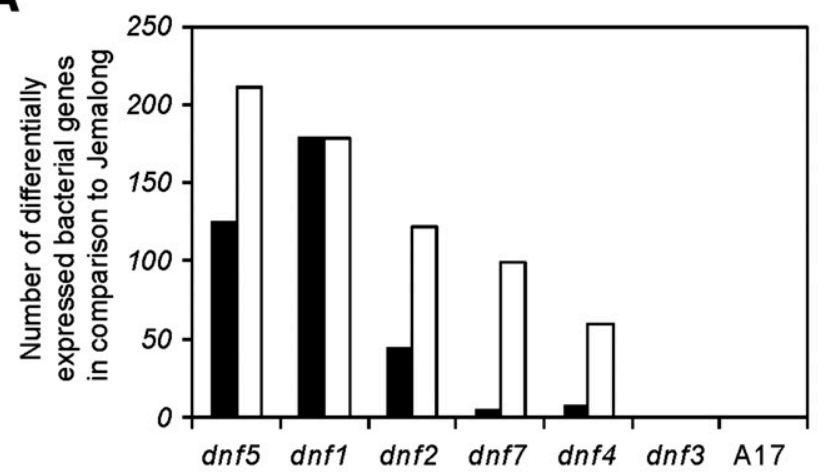

B

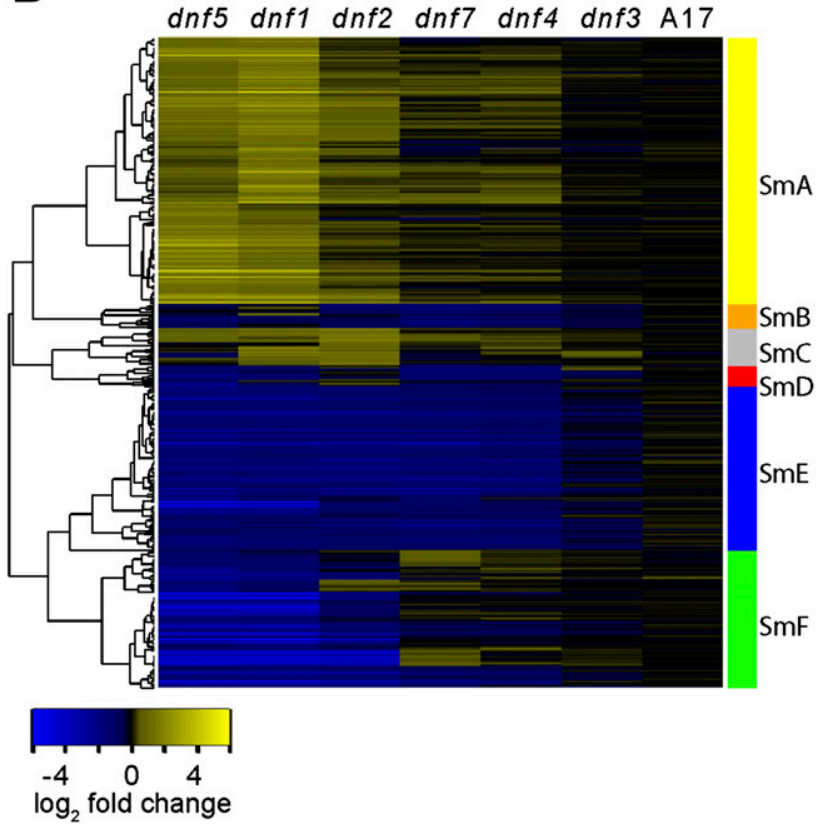

C
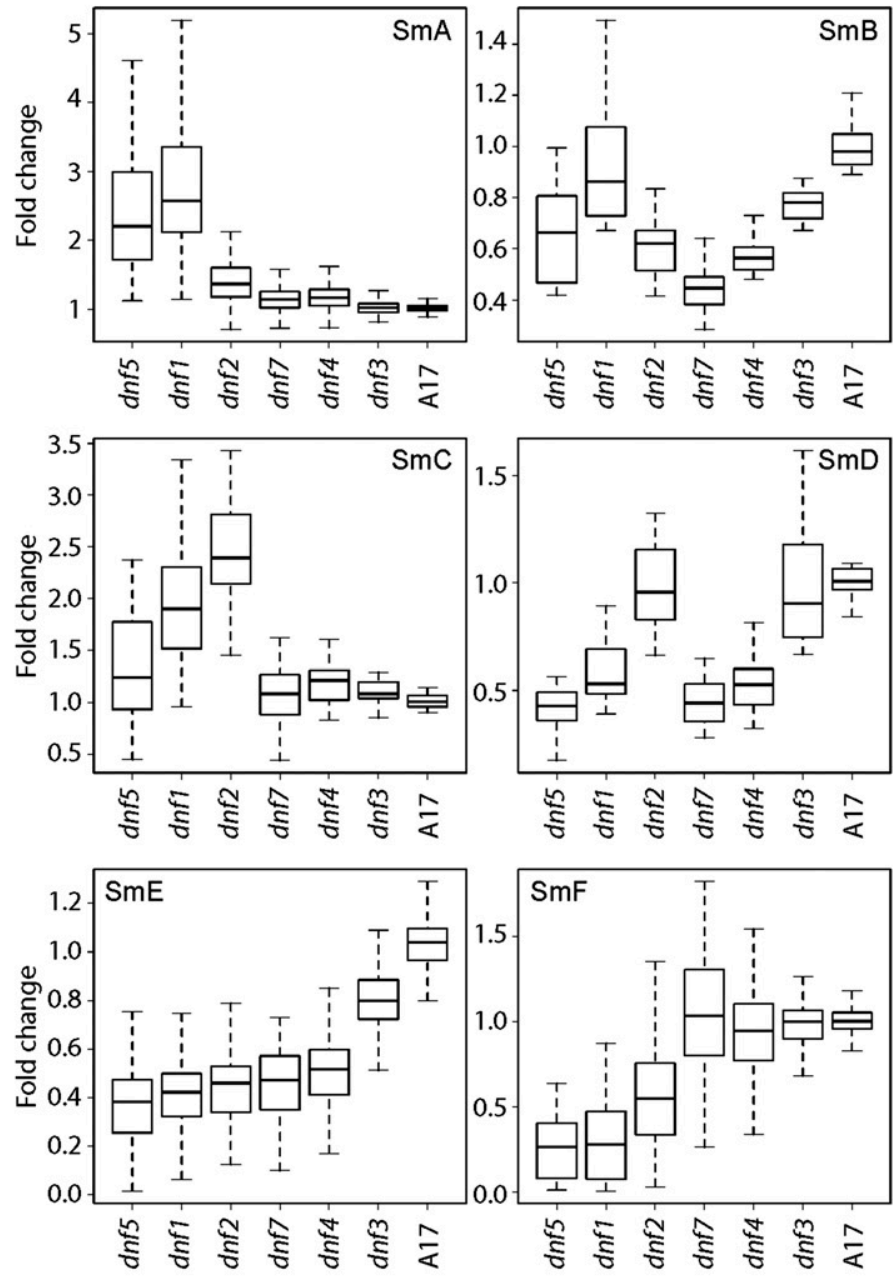

Fig. 2. Transcriptomic analysis of Sinorizobium meliloti gene expression in nodules from dnf plants. A, The number of differentially regulated bacterial genes in the indicated plant mutants compared with those in wild-type Medicago truncatula cv. Jemalong root nodules (adjusted $P$ value $=0.05$, fold change $>2$ ). The black columns represent genes with increased expression levels compared with wild type and the white columns represent genes with reduced expression levels. B, Heatmap and hierarchical clustering of bacterial genes that are differentially expressed in comparison with $M$. truncatula cv. Jemalong wild-type nodules. The color scale bar indicates the fold change of gene expression in comparison with wild-type nodules; the color sidebar highlights six bacterial gene clusters (SmA to SmF). C, Boxplot representations of gene expression profiles of each cluster. The box indicates the upper and the lower quartile, the bar indicates the median and the whiskers indicate the highest and lowest values excluding outliers. Outliers were defined as values that are higher than $1.5 \times$ the interquartile range above the upper quartile or lower than $1.5 \times$ the interquartile range below the lower quartile.

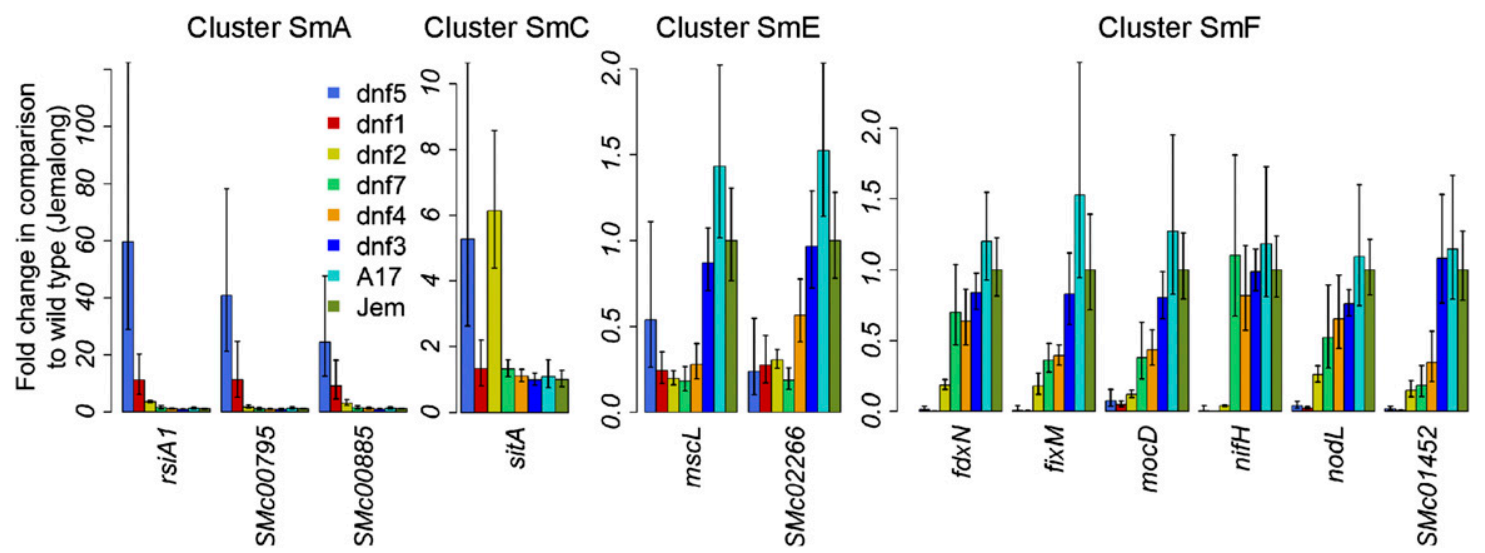

Fig. 3. Validation of Affymetrix GeneChip data by quantitative reverse transcription-polymerase chain reaction (qRT-PCR). The relative expression levels of 12 Sinorizobium meliloti genes from four clusters were assayed by qRT-PCR; expression levels were normalized to an internal control (nuoL). The data are expressed as the expression ratios of different plant lines to Medicago truncatula cv. Jemalong. Each data point is an average of three replicates; error bars indicate standard deviation of the fold change. 
this elevated expression level of FeuP and its target genes in early-arrest mutants suggests that FeuP/Q-mediated cyclic $\beta$-glucan production is relevant to bacterial survival in infection threads. Conversely, lower feuP expression in intermediatearrest and wild-type nodules indicates that cyclic $\beta$-glucan production is downregulated after bacteria are released from the infection thread to form symbiosomes.

Regulatory mutations that lead to over- or under-production of EPS-I (succinoglycan) cause parallel expression changes for a canonical group of EPS-associated genes. These same genes
A

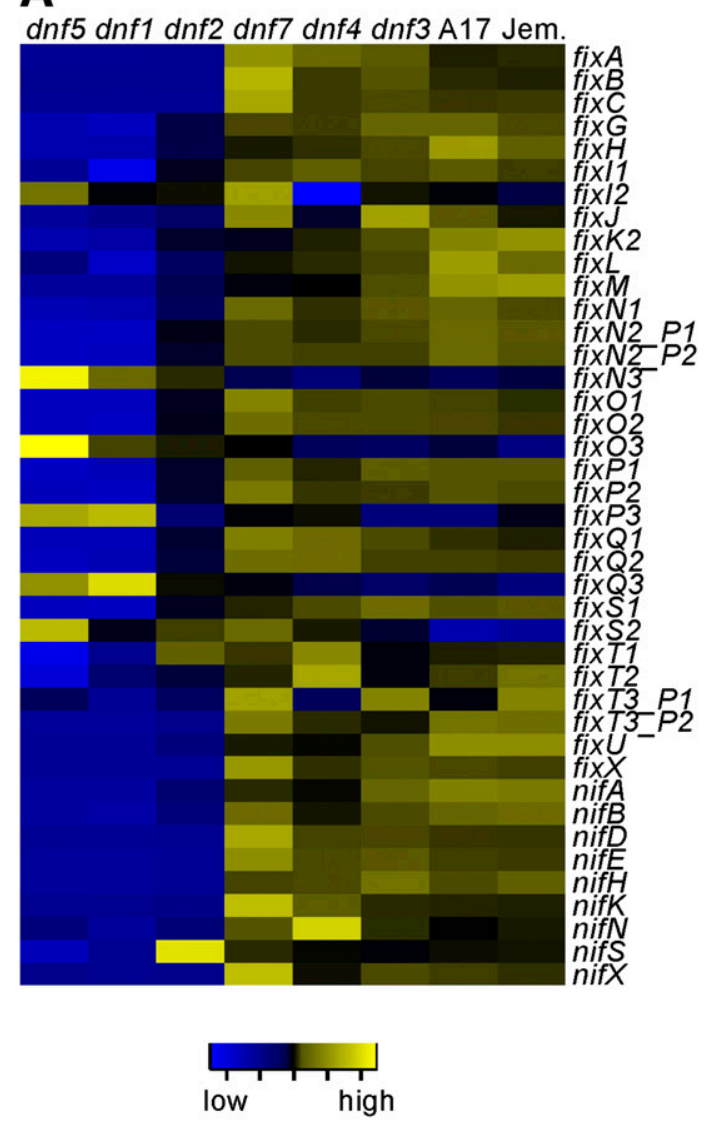

C

dnf5 dnf1 dnf2 dnf7 dnf4 dnf3 A17 Jem.

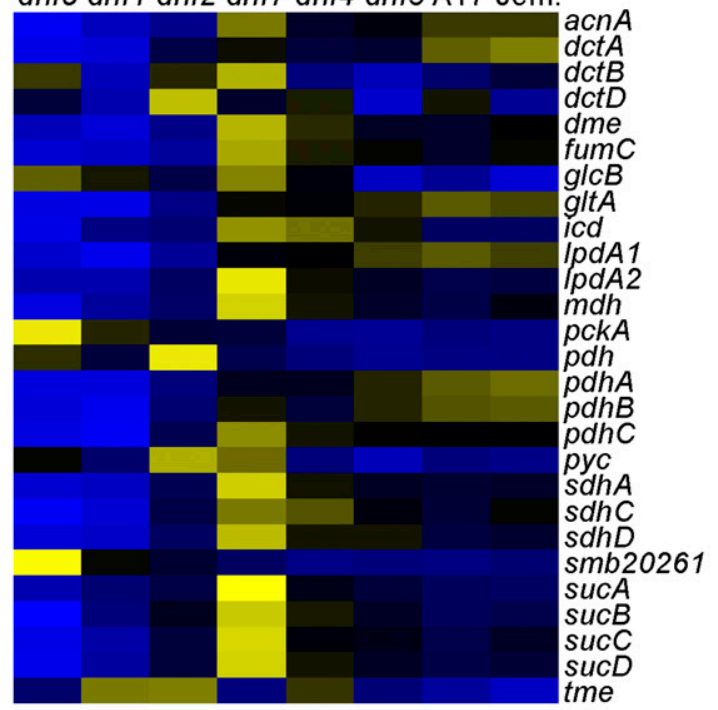

B

dnf5 dnf1 dnf2 dnf7 dnf4 dnf3 A17 Jem.
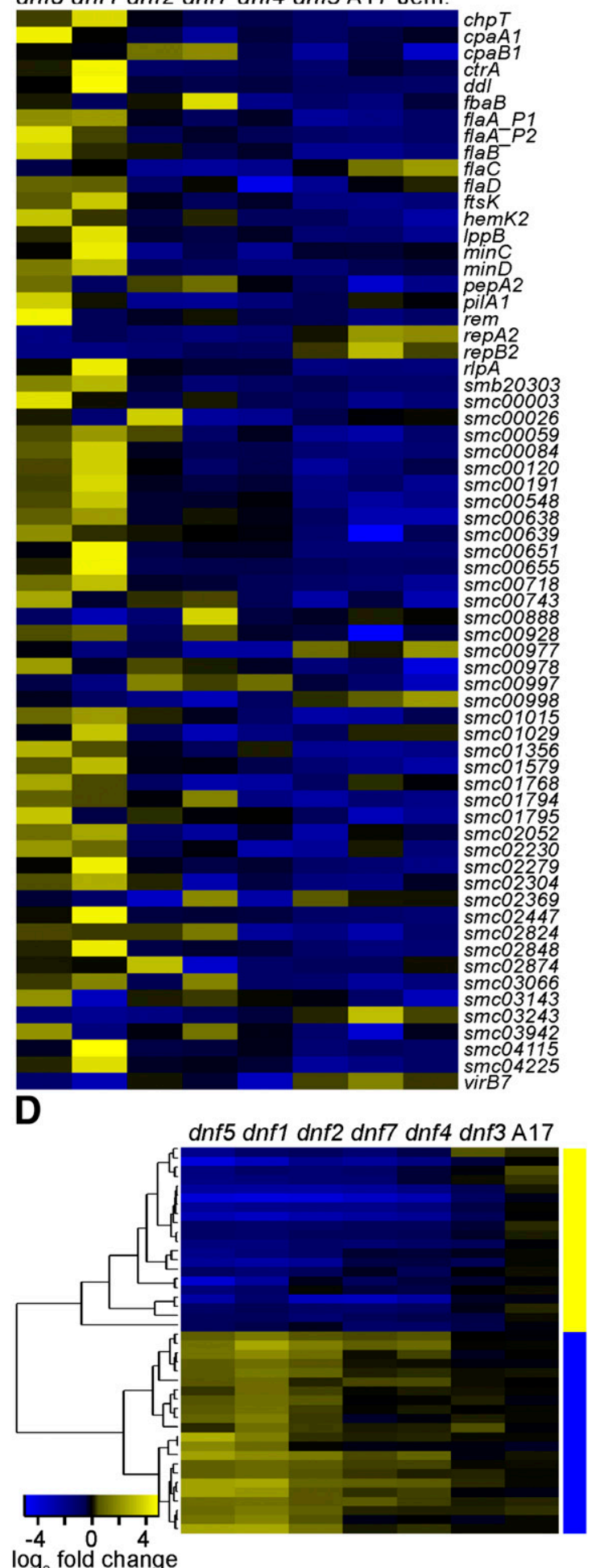

Fig. 4. Several processes are regulated during symbiosis. A, Expression profiles of $n i f$ and fix genes, B, ctrA-controlled genes (De Nisco et al. 2014), and $\mathbf{C}$, tricarboxylic acid cycle genes. The signal intensities are scaled for each gene, as indicated by the color scale bar. D, expression profiles and hierarchical clustering of bacterial sRNA probe sets that are significantly changed (adjusted $P$ value $<0.05$, fold change $>2$ ) relative to wild-type nodules. The color scale bar indicates the $\log _{2}$ fold change of gene expression; a color sidebar highlights two main clusters. 
are expressed at higher levels in early-arrest nodules than in wild-type nodules (Chen et al. 2009; Gibson et al. 2007; Wells et al. 2007). EPS such as succinoglycan (or the related galactoglucan) is essential for symbiosis in S. meliloti strains (Cheng and Walker 1998; Pellock et al. 2000). Our results support the proposal that succinoglycan production is required during the infection thread stage and, then, is repressed when the bacteria differentiate into bacteroids in symbiosomes.

Genes regulated by the polarity determinant podJ (Fields et al. 2012) are significantly enriched in early-arrest nodules. One of the main transcriptomic changes in a podJ mutant is the elevated expression of succinoglycan biosynthesis genes (Fields et al. 2012). Therefore, it is likely that podJ-regulated genes are enriched in early-arrest nodules because succinoglycan biosynthesis is activated both in the podJ mutant and in early-arrest nodules.

\section{Stress response.}

During symbiosis, bacteria are exposed to different environmental stresses including ROS and reactive nitrogen species (Downie 2010; Gibson et al. 2008). We note that the cluster typifying early-arrest mutants (SmA) includes general stress response sigma factor $r p o E 2$ and its antisigma factor $r s i A 1$ and is highly enriched for RpoE2 target genes (e.g., 48 of 193 genes that are upregulated upon RpoE2 overexpression, $P=1.19 \times$ $10^{-30}$ [Schlüter et al. 2013]). PGSEA also shows that RpoE2 target genes are expressed strongly in early-arrest nodules. In addition, transcripts for genes that are induced in response to environmental stresses such as nitric oxide stress, zinc stress, acidic stress, osmotic stress, and heat shock are also enriched in early-arrest nodules (Barnett et al. 2012; Domínguez-Ferreras et al. 2006; Hellweg et al. 2009; Meilhoc et al. 2010; Rossbach et al. 2008; Sauviac et al. 2007). We see two, not mutually exclusive interpretations: i) the increased expression of stress genes in early-arrest nodules suggests that the general stress response is active in infection threads due to inducers such as oxidative stress; ii) it is possible that the general stress response is activated due to premature senescence of early-arrest nodules. The hypothesis that the general stress response is activated in infection threads is in agreement with the observation that many rpoE2 regulated genes are also highly expressed in young wild-type nodules in which bacteria are predominantly found in infection threads (Capela et al. 2006; Sauviac et al. 2007).

Our analyses also implicated the heat-shock sigma factor RpoH in symbiosis. S. meliloti encodes two RpoH-like sigma factors. RpoH1 is required for successful symbiosis; RpoH2, the other heat-shock sigma factor in S. meliloti, is part of the rpoE2 regulon (Sauviac et al. 2007; Schlüter et al. 2013). $\mathrm{RpoH} 2$ is not required on its own for efficient symbiosis but an rpoH1 rpoH2 double mutant is inhibited during earlier symbiotic stages than an rpoHl single mutant (Barnett et al. 2012; Mitsui et al. 2004; Oke et al. 2001). The rpoH2 gene and four of its 41 known target genes fell into cluster SmA (Barnett et al. 2012). The RpoH2 target gene set was enriched in $d n f l$ and $d n f 5$ nodules. Increased expression of $\mathrm{rpoH} 2_{2}$ in early-arrest mutants and the severe phenotype of the rpoH1 rpoH2 mutant argue that $\mathrm{RpoH} 2$ is active during early symbiotic stages. RpoH1 mediates expression of 282 genes under heat-shock conditions (Barnett et al. 2012), and these targets were enriched in clusters containing genes highly expressed in $d n f 2$ nodules (clusters SmC, SmD) (Fig. 2C). Genes regulated by $\mathrm{RpoH} 1$ during acid shock (de Lucena et al. 2010) are similarly overexpressed in $d n f 2$ nodules. These data indicate that RpoH1 is highly active in $\operatorname{dnf} 2$ nodules. Since $\operatorname{dnf} 2$ nodules contain elongated bacteroids (Bourcy et al. 2013) and nodule development is arrested later in $d n f 2$ nodules than in early-arrest nodules but earlier than in $d n f 4$ and $d n f 7$ nodules, we suggest that RpoH1 is active shortly after the bacteria are released into symbiosomes and does not remain active during later symbiotic stages.

\section{Metabolic changes during nodule development.}

Metabolic remodeling is a characteristic of bacterial differentiation, and underlying gene expression changes may occur due to the novel plant environments that the bacteria traverse during infection. While free-living bacteria utilize diverse carbon compounds, bacteroids appear to use only plantprovided dicarboxylic acids as carbon and energy sources. These dicarboxylic acids are taken up via DctA and metabolized via the tricarboxylic acid (TCA) cycle and provide energy for nitrogen fixation (Udvardi and Poole 2013). We found that wild-type and intermediate-arrest $d n f$ mutant nodules had abundant TCA-cycle gene transcripts, but such transcripts were scarce in early-arrest nodules (Fig. 4C). Furthermore, TCAcycle genes are significantly enriched in cluster SmE (Supplementary Table S6). Several gene-function groups related to small-molecule metabolism or energy metabolism (such as the pyruvate dehydrogenase, energy transfer, electron transport subgroups) are well-represented in cluster SmF, which contains genes that display high expression levels in intermediate-arrest and wild-type nodules but not in early-arrest nodules. Genes known to be induced during starvation (Capela et al. 2006; Krol and Becker 2011; Sauviac et al. 2007) or during growth on succinate instead of glucose (Barnett et al. 2004) are more highly expressed in early-arrest and $d n f 2$ nodules than in wildtype nodules. Taken together these findings are consistent with the hypothesis that carbon supply to bacteria is limited in early-arrest nodules but, once the nodules develop to intermediate stages and beyond, availability of plant-derived dicarboxylic acids increases. Thus, bacterial carbon metabolism switches to the utilization of dicarboxylic acids once the bacteria are released into plant cells and bacteroid differentiation starts. High expression levels of TCA-cycle and energy-metabolism genes in nitrogen-fixation defective intermediate-arrest nodules suggest that the bacteria have access to plant-derived carbon sources even though they do not fix nitrogen efficiently.

\section{Processes specifically expressed during later symbiotic stages.}

We looked at the difference between intermediate-arrest nodules and fully mature wild-type nodules for clues about bacteroid function in the final stages of endosymbiosis. Few genes were expressed at significantly higher levels $(P<0.05$, fold change $>1$ ) in the intermediate-arrest nodules from $d n f 4$ and $d n f 7$ plants than in wild-type nodules. Genes that were expressed at lower levels in the intermediate-arrest nodules mostly corresponded to cluster SmE, which contains 122 genes that are specifically expressed in wild-type nodules, and are, therefore, characteristic of mature nodules. Cluster $\mathrm{SmE}$ includes several genes (smoE, agpA, agpD, smb21302) involved in sugar transport and metabolism; this may indicate that bacteria in mature nodules do not use solely dicarboxylates but, also, plant derived sugars such as melibiose and fucose. Other late-function genes that may be used to degrade alternative carbon sources are nerA (glycerol trinitrate reductase), $f d s G$ (formate dehydrogenase), gabDl (succinate semialdehyde dehydrogenase), and $d p p A 1$ (peptide transport).

A particularly prominent class of genes in cluster SmE is "elements of external origin" with transposon-related functions. In addition, several regulators, such as the motility regulator vis $N$, succinoglycan regulator exoX, and the alternative sigma factors rpoN, rpoE3 and rpoE8, are found in cluster $\mathrm{SmE}$. We speculate that some of these functions might relate to 
functions for surviving one or both nodule maturation and senescence.

\section{sRNA expression.}

To identify symbiotically regulated sRNAs, we matched probe sets for intergenic sequences by BLAST search to 389 previously identified sRNAs (del Val et al. 2007; Schlüter et al. 2010, 2013). Of these 389 sRNAs, 43 are differentially expressed in dnf mutant nodules (Supplementary Table S7). Clustering shows that different sRNAs are expressed during different symbiotic stages (Fig. 4D). Approximately half of the sRNAs (22) are expressed at higher levels in early- and intermediate-arrest mutant nodules than in wild-type nodules, which suggests that they are predominantly expressed in infection threads and during bacteroid differentiation. In contrast, the other 21 sRNAs are most highly expressed in wild-type nodules, suggesting that they are expressed after the onset of nitrogen fixation in mature nodules (Fig. 4D).

\section{Differential expression of plant genes in $d n f$ mutant nodules.}

Our custom Symbiosis Chip allows us to analyze plant and bacterial gene expression simultaneously (discussed below). A total of 1,255 plant gene probe sets showed significant changes between mutant and wild-type nodules (Supplementary Table S8) and cluster analysis yielded nine groups (MtA to MtI) of similar expression profiles (Fig. 5; Supplementary Table S9). We compared our results on plant gene expression in developmentally arrested nodules with the results of studies on plant gene expression in different root-nodule zones (Limpens et al. 2013; Roux et al. 2014). These comparisons show that genes that were previously detected in the meristem and infection zone are expressed at significantly higher levels in early-arrest nodules than in wild-type nodules; conversely, genes that are expressed in the interzone II-III or nitrogenfixation zone are expressed at significantly lower levels in early-arrest nodules than in wild-type nodules (Supplementary Table S10).

Clusters MtA, MtB, MtC, and MtD, comprising genes expressed predominantly in late-arrest and wild-type nodules, contain many genes that are most highly expressed in the nitrogen-fixation zone, the interzone II-III, or in infected cells of the nitrogen-fixation zone. The clusters are distinguishable in that genes of MtA, MtB, and MtC, which encode, for example, leghemoglobins and many NCR peptides, are expressed to varied extents in intermediate-arrest nodules, while those genes in MtD (e.g., late nodulins) are exclusively expressed in wild-type but not in the relatively normal $\operatorname{dnf} 3$ mutant nodules. Clusters $\mathrm{MtE}, \mathrm{MtF}, \mathrm{MtG}$, and $\mathrm{MtH}$ consist of genes that are generally expressed at higher levels in early- and intermediatearrest nodules, such as genes encoding peroxidases, calmodulins, and chalcone synthases. Many genes in clusters MtE, $\mathrm{MtF}, \mathrm{MtG}$, and $\mathrm{MtH}$ were previously found to be highly expressed in the meristem, the infection zone, and in uninfected cells of the nitrogen-fixation zone (Limpens et al. 2013; Roux et al. 2014). The similarities between plant gene expression in dnf mutants and different root-nodule zones provide additional evidence that nodules from $d n f$ mutants are enriched for plant and bacterial cells at different developmental stages.

A hallmark of plant differentiation in mature nodules is the presence of specialized heme-containing proteins such as leghemoglobins, which give nodules their characteristic pink color. Leghemoglobins are required to establish microoxic conditions and are essential for nitrogenase activity and maximal nif gene expression (Ott et al. 2005, 2009). Analysis of clusters based on MapMan classification (version Mt_Mt3.5_0411) showed that 14 heme-containing redox proteins are expressed at low levels in early-arrest and $d n f 2$ nodules (Supplementary Table S11). Eleven of these probe sets detect leghemoglobin transcripts. While leghemoglobin expression levels are similar in $d n f 4, \operatorname{dnf7}, \operatorname{dnf} 3$, A17, and Jemalong nodules, only $d n f 3$, A17, and Jemalong nodules display the characteristic pinkish color, whereas $d n f 4$ and $d n f 7$ nodules are white. Thus, levels of the pink, reduced form of leghemoglobin protein appear to be lower in intermediatearrest nodules despite similar transcript levels. This points to control beyond transcription, such as translation, maturation, or stability of leghemoglobin proteins. Since a reduction of functional leghemoglobin levels would be expected to cause nitrogen deficiency, future analyses of leghemoglobin proteins in $d n f 4$ and $d n f 7$ nodules may reveal how the mutations in $d n f 4$ and $d n f 7$ impact symbiosis.

Comparison of early-arrest with wild-type nodules might be useful, not only by showing what is missing in early nodules due to a genetic block in differentiation but by revealing functions that may be transient in nodule development. On the other hand, early-arrest nodules might, instead, be characterized by abnormal expression due to inappropriate developmental signals with consequent stress responses. We observed several functional groups to be expressed at higher levels in early-arrest mutants. The strongest differences are observed for biotic stress, ascorbate and glutathione redox proteins, and phenylpropanoid and flavonoid metabolism. Biotic stress genes are also expressed at higher levels in intermediate-arrest nodules, suggesting that biotic stress genes are active during the early stages of symbiosis and downregulated with the onset of nitrogen fixation. Activation of the defense response during microbial infection causes the release of ROS. Thus, ascorbate and glutathione redox proteins and other proteins with a role in detoxification of ROS, including thioredoxins, glutaredoxins, and peroxidases (Becana et al. 2010), are probably expressed highly in early-arrest nodules to increase resistance toward elevated ROS levels. We cannot exclude the possibility that elevated biotic stress gene expression and elevated ROS levels are a result of premature senescence in early-arrest nodules. However, findings of high concentrations of ascorbate, glutathione, and antioxidant proteins in healthy nodules (Matamoros et al. 2003) suggest that antioxidant proteins are expressed during normal nodule development. In addition, cysteine proteases, which can be used as senescence markers (Van de Velde et al. 2006), were expressed at lower levels in early- than intermediate-arrest nodules and were assigned to clusters MtA (Medtr4g047610, Medtr4g107930, Medtr4g047610) and MtB (Medtr5g022560, Medtr4g079800). This suggests that senescence has either not been initiated or has not progressed very far in early-arrest nodules.

Flavonoids and phenylpropanoids are important signaling molecules during the early stages of the symbiosis as inducers of nodulation gene expression and play a role in the plant defense response (Stafford 1997). The differential expression of genes for $\mathrm{NAD}(\mathrm{P}) \mathrm{H}$ dependent $6^{\prime}$ deoxychalcone synthase, isoliquiritigenin $O$-methyltransferase, and isoflavone reductase would be consistent with phytoalexin production occurring in early-arrest mutants. Flavonoid and phenylpropanoid metabolism are also increased in nodules formed by a bacterial exo $A$ mutant (Maunoury et al. 2010; Moreau et al. 2011), and it has also been reported that some $d n f 2$ nodules exhibit a dark-brown pigmentation consistent with the accumulation of phenolic compounds (Bourcy et al. 2013). This raised the question whether flavonoid and phenylpropanoid biosynthesis in plant and bacterial mutants results from early senescence or if it reflects gene expression during early symbiotic stages. Since several probe sets for flavonoid biosynthetic proteins including 
those for isoflavone reductase, isoliquiritegenin reductase, caffeoyl-CoA methyltransferase and 4 coumarate -CoA ligase were detected at higher levels in the nodule tip than in the interzone II-III (C. Lang and S. R. Long, unpublished; Roux et al. 2014), we speculate that there may be early deployment of plant flavonoid-mediated plant defenses that are subsequently downregulated during symbiosome formation.

\section{Expression of NCR peptides in mutant nodules.}

In Medicago spp. and other legumes that induce bacteroid differentiation, infected plant cells express genes for nodulespecific glycine-rich (NGR) and NCR secreted peptides. NCR peptides are targeted to symbiosomes, affect bacterial growth, and induce bacteroid-like morphological changes (Kondorosi et al. 2013). Treatment of $S$. meliloti cultures with the purified NCR247 peptide results in blockage of cell division but not DNA replication (Penterman et al. 2014). We observed higher NCR- and NGR-peptide expression levels in intermediate- and late-arrest than in early-arrest nodules. Correspondingly, most NCR- and NGR-probe sets were assigned to cluster MtA (131 NCR, two NGR probe sets) or MtC (38 NCR, six NGR probe sets). One NCR probe set (Medtr1g042895) fell into cluster $\mathrm{MtD}$, indicating that it is expressed specifically in nitrogenfixing nodules. Given their antimicrobial properties and expression profiles, NCR peptides may play a role in controlling bacterial infection during intermediate and late symbiotic stages after plant ROS- and flavonoid-mediated plant defense mechanisms are downregulated.

The maturation and subsequent transport of NCR peptides depends on the DNF1-signal peptidase (Van de Velde et al. 2010; Wang et al. 2010). In dnf mutant analyses, we found that the $d n f 1$ gene itself is expressed at similar levels in all plants

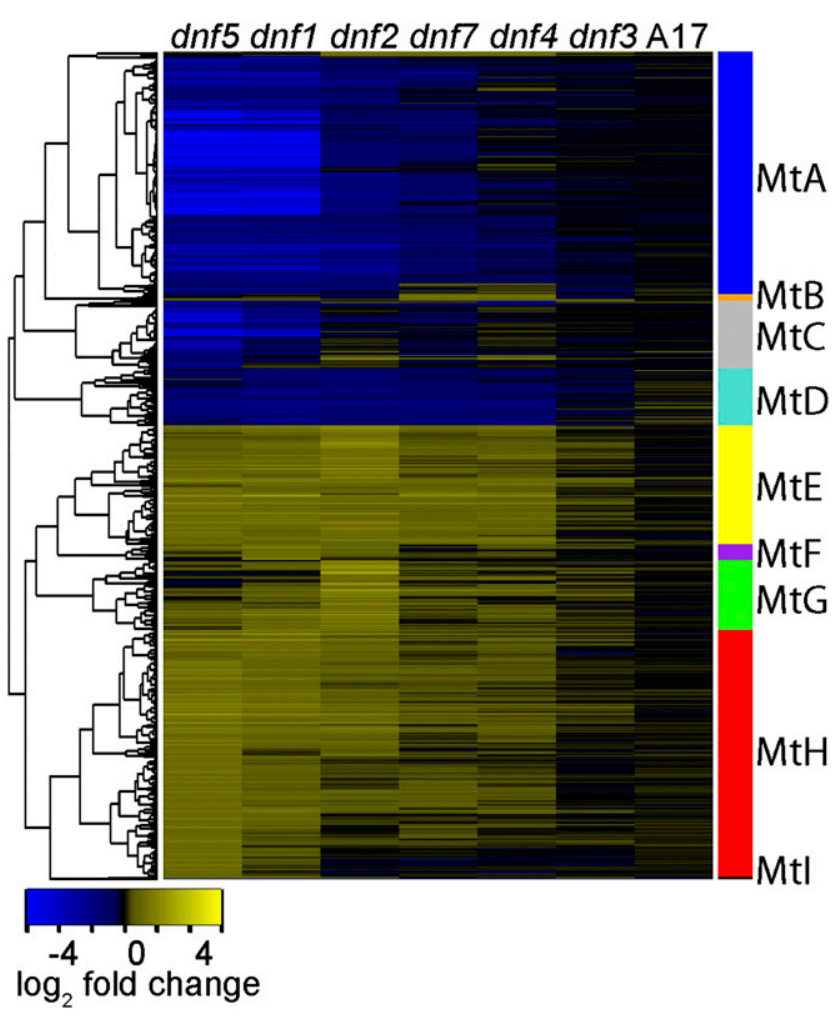

Fig. 5. Heatmap diagram and hierarchical clustering of plant probe sets that are significantly changed (adjusted $P$ value $=0.05$, fold change $>2$ ) in comparison with Medicago truncatula cv. Jemalong wild-type nodules. The color scale bar for expression level is located at the figure bottom and indicates the $\log _{2}$ fold change of gene expression relative to wild-type nodules. The color sidebar highlights nine plant gene clusters (MtA to MtI). except the dnfl mutant, in which expression was not detected. Low expression of NCR peptide-encoding genes in the $d n f 1$ mutant indicates that NCR peptide-encoding genes are not fully expressed in the absence of a functional NCR maturation and secretion system. It is possible that failure to export NCR peptides results in intracellular accumulation of NCR pepetides and subsequent downregulation of NCR biosynthesis by a negative-feedback mechanism. Alternatively, NCR peptide biosynthesis may be downregulated due to aberrant nodule development in $d n f 1$ nodules.

Transcriptomic studies demonstrated the effects of NCR peptides on S. meliloti in culture (Penterman et al. 2014; Tiricz et al. 2013). We asked whether genes that are regulated in response to NCR peptide treatment in culture are enriched in certain plant mutants. We were surprised to find that genes that are induced in culture by NCR peptides were expressed at significantly higher levels in early-arrest $(d n f 1, d n f 5)$ and $d n f 2$ mutant nodules than in intermediate-arrest or wild-type nodules. Similarly, genes whose expression was decreased in response to NCR peptide treatment in cultures were expressed at lower levels in early-arrest than in wild-type nodules. This was unexpected. Since it had been proposed that NCR peptides are responsible for bacteroid differentiation (Kondorosi et al. 2013), one might thus expect higher NCR-induced gene expression in late-arrest and wild-type nodules. Bacterial cells in nodules with the lowest levels of NCR peptide expression, such as $d n f 1, d n f 2$ and $d n f 5$, show similar behaviors as NCR peptidetreated cells. One interpretation is that cultured cells respond to NCR peptide treatment by activation of stress-response genes and cell-envelope changes including activation of succinoglycan biosynthesis and cyclic $\beta$-glucan production (Penterman et al. 2014; Tiricz et al. 2013). These functions are indeed expressed at higher levels in early-arrest nodules than in wild-type nodules, but they are plausibly caused, not by NCR peptides, but by other environmental stress factors such as plant-produced ROS, characteristic of early symbiosis. In addition, we are aware that the $S$. meliloti response to a single NCR peptide in liquid cultures almost certainly differs from response of nodule bacteria that encounter additional stresses and multiple species of NCR peptides.

\section{Conclusion.}

Earlier reports have identified bacterial exposure to plantroot exudates as a key transition toward the symbiotic state (Peters and Long 1988). Also, transcription profiles of bacteria in nodules (Barnett et al. 2004; Becker et al. 2004; Capela et al. 2006; Roux et al. 2014) show that hundreds of bacterial genes are up- or downregulated in response to the accumulated effects of nodule development, presumably reflecting activity of many plant genes over time. In this study, we used developmentally arrested $d n f$ plant mutants to study transcriptional changes during root-nodule development in both symbiotic partners, $S$. meliloti and M. truncatula. Use of mutants allowed us to observe gene expression changes that are obscured in whole mature nodules and to identify four stages of bacterial differentiation within the nodule that correspond to the activity of individual plant genes.

We systematically compared our results to previous $S$. meliloti microarray studies and carried out functional enrichment analyses to identify processes that are characteristic of different symbiotic stages. During the infection thread stages, we observed expression of certain cell cycle- and enveloperelated genes. Several genes whose products deal with stressrelated functions were also expressed predominantly during early symbiotic stages, while other stress-related genes, such as the heat-shock sigma factor $\mathrm{rpoHl}$ are expressed slightly later and, thus, may play a role after bacteria are released into 
symbiosomes. Bacteroid differentiation and nitrogen fixation are characterized by increased transcript levels of genes with roles in the TCA cycle and nitrogen fixation. We analyzed $M$. truncatula gene expression with an emphasis on processes that may control bacterial infection. Our results indicate that general plant defense responses such as ROS production and phenylpropanoid metabolism play a role in the infection zone. During later symbiotic stages, transcription of genes involved in these processes is suppressed and nodule-specific peptides (NCR and NGR peptides) become the primary mechanism to control bacterial infection. A potential caveat of using plant mutants to study bacteroid differentiation is that senescence may be induced prematurely in mutants and affect plant and bacterial gene expression. However, strong correlations of plant and bacterial gene expression in $d n f$ nodules with previous nodulation time-course studies and laser-capture microdissectionbased studies of genes support future use of plant mutants for analysis of bacterial differentiation. A major advantage of the plant mutant approach is that, unlike transcriptomic analyses (which can be carried out after amplification of scarce material from laser microdissection samples), developmentally arrested nodules can be easily obtained in large quantities, an obvious asset for proteomic, metabolomic, and other studies.

\section{MATERIALS AND METHODS}

Plant cultivation, inoculation, and root-nodule harvest.

The wild-type strain Sinorhizobium meliloti CL150 was used throughout this study. CL150 is a S. meliloti 1021 derivative, corrected for point mutations in pstC and ecfRl (Schlüter et al. 2013). Bacterial cultures were prepared for plant inoculation as described previously (Mitra and Long 2004). Medicago truncatula [Gaertn.] cvs. Jemalong, A17, and $d n f$ plant seeds were lightly scratched with sandpaper and were sterilized in undiluted bleach for $5 \mathrm{~min}$. Seeds were rinsed with sterile water and were imbibed for $8 \mathrm{~h}$ at room temperature and $48 \mathrm{~h}$ at $4^{\circ} \mathrm{C}$, were germinated overnight in inverted petri dishes in the dark, and were planted into presterilized vermiculite in cone-tainer tubes (Stuewe \& Sons). Plants were watered every third day with $5 \mathrm{ml}$ of $0.1 \times$ buffered nodulation medium (BNM) (Ehrhardt et al. 1992). Five-day-old seedlings were inoculated with $5 \mathrm{ml}$ of a suspension (optical density at $600 \mathrm{~nm}=0.1$ ) of CL150 in $0.1 \times$ BNM.

\section{RNA purification, amplification,} and microarray hybridization.

Samples for transcriptomic analysis were obtained from root nodules harvested 21 days after inoculation, placed in liquid nitrogen, and stored at $-80^{\circ} \mathrm{C}$. For each of the three replicates,
9 to 17 plants were used. Root nodules from $d n f$ mutants and from wild-type cultivars Jemalong and A17 were placed in $30 \mu \mathrm{l}$ of RLT buffer (RNeasy mini kit; Qiagen) and frozen in liquid nitrogen. The nodules were ground with a microcentrifuge tube pestle as the buffer thawed. The lysate was brought to a volume of $450 \mu \mathrm{l}$ with RLT buffer and processed through a Qiashredder column (Qiagen) and an RNeasy Mini spin column (Qiagen). The RNA was DNase-treated (DNase I; Thermo Fisher Scientific) in the presence of RNase inhibitor (SuperaseIN) (Barnett et al. 2004). The DNase-treated RNA was repurified using RNeasy MinElute columns (RNeasy MinElute kit). RNA quality and quantity were assayed using Bioanalyzer RNA Nano chips (Agilent). Template RNA (1 $\mu \mathrm{g})$ was amplified and was biotin-labeled, using the MessageAmp Bacteria kit (Ambion). Amplified RNA $(20 \mu \mathrm{g})$ was fragmented in $40 \mu \mathrm{l}$ of $200 \mathrm{mM}$ Tris-acetate, $\mathrm{pH} 8.1,500 \mathrm{mM}$ potassium acetate, $150 \mathrm{mM}$ magnesium acetate at $94^{\circ} \mathrm{C}$ for $35 \mathrm{~min}$. The reaction was brought to $78.5 \mu \mathrm{l}$ with water and was hybridized to Affymetrix GeneChips as described previously (Barnett et al. 2004).

\section{Microarray analysis.}

Hybridization experiments used a custom Symbiosis Chip that contains probe sets for the complete $S$. meliloti genome $(6,247$ probe sets for open reading frames, 5,788 probe sets for intergenic regions) and 10,893 probe sets for M. truncatula tentative consensus (TC) sequences (Barnett et al. 2004). We updated the $M$. truncatula annotations of our GeneChip by finding sequence identity between the TC sequences used to design the microarray and the updated $M$. truncatula genome sequence, based on the annotation versions Mt3.5 and Mt4.0 (Young et al. 2011), using BLASTn (National Center for Biotechnology Information [NCBI] BLAST 2.2.27+). The latest annotations of $S$. meliloti genes were obtained from the EnsemblBacteria database release 22 (Kersey et al. 2014). To study bacterial sRNA expression, we matched AffyChip probe sets for bacterial intergenic regions to noncoding RNAs found by Schlüter et al. (2013) and experimentally verified sRNAs found by del Val et al. (2007) by BLASTn. We only considered probe sets for intergenic sequences that displayed a $100 \%$ match to a sRNA for at least $100 \mathrm{bp}$. In addition, we included sRNAs that were identified with our chip by Schlüter et al. 2010. Specifically, we included sRNAs encoded in intergenic regions (transencoded sRNA) and sRNAs encoded in antisense orientation of an annotated open reading frame (cis-encoded sRNA) (Schlüter et al. 2010).

Affymetrix CEL files were analyzed using $\mathrm{R}$ and BIOCONDUCTOR software packages (Gentleman et al. 2004) (R Foundation for Statistical Computing, Vienna, Austria). Probe

Table 1. Key characteristics of Sinorhizobium meliloti gene clusters

\begin{tabular}{|c|c|c|c|}
\hline Cluster & No. of genes & Profile description & Characteristic genes and processes \\
\hline SmA & 197 & $\begin{array}{l}\text { Increased expression in } d n f \text { nodules, } \\
\text { especially } d n f 1 \text { and } d n f 5\end{array}$ & $\begin{array}{l}\text { NADH dehydrogenase (nиоA2, пиоK2, пиоJ2), } \\
\text { stress response (rpoE2, rsiA1, rрoE5, rрoH2), } \\
\text { cyclic } \beta \text {-glucan biosynthesis }(\text { feuP, ndvA), cell cycle } \\
\text { (ctrA, dnaA, fts } Z 1, \text { minE })\end{array}$ \\
\hline $\mathrm{SmB}$ & 18 & $\begin{array}{l}\text { Decreased expression in } d n f \text { nodules, } \\
\text { except for } d n f 2 \text { nodules }\end{array}$ & $\begin{array}{l}\text { Regulators (lsrB, exs }) \text {, phenyl acetic acid } \\
\text { degradation (paaC) }\end{array}$ \\
\hline $\mathrm{SmC}$ & 28 & $\begin{array}{l}\text { Increased expression in } d n f \text { nodules, } \\
\text { especially } d n f 2\end{array}$ & $\begin{array}{l}\text { Manganese transport }(\operatorname{sit} A B C D), \text { proteases } \\
(\operatorname{deg} P 1, f t s H, \operatorname{clp} P 1, \operatorname{clpS} 1, \operatorname{clp} X)\end{array}$ \\
\hline SmD & 15 & Increased expression in $d n f 1$ and $d n f 2$ nodules & $n t r R 2$, glutaredoxin $(\mathrm{grxC})$ \\
\hline SmE & 122 & Decreased expression in $d n f$ nodules & $\begin{array}{l}\text { Regulators (rpoE3, rpoE8, rpoN), sugar } \\
\text { utilization }(\text { fucU, smoE } \text {, agpA, agpU) }\end{array}$ \\
\hline $\mathrm{SmF}$ & 102 & $\begin{array}{l}\text { Decreased expression in } d n f 1, d n f 5 \text {, and } \\
\text { (partially) } d n f 2 \text { nodules }\end{array}$ & $\begin{array}{l}\text { Nitrogen fixation (nif and fix), dicarboxylic acid } \\
\text { metabolism and tricarboxylic acid cycle } \\
(d c t A, p d h A a, p d h B b, p d h C, l p d A 1 \text { gltA, } m d h \text {, } \\
\text { sucBCD, sdhABCD) }\end{array}$ \\
\hline
\end{tabular}


summarization and normalization were carried out with the AFFY package and the RMA algorithm (Irizarry et al. 2003). To account for varying plant to bacterial RNA ratios in different samples, normalization was conducted separately for M. truncatula and S. meliloti probe sets. PCA was carried out with the RMA normalized bacterial expression data using $\mathrm{R}$ with the "prcomp" function. The PCA plot was created using "ggbiplot" in R. The LIMMA software package was used to identify differentially expressed genes (Smyth 2005). We calculated fold changes for pairwise comparisons of mutants to the Jemalong wild-type. We used the Benjamini and Hochberg (1995) adjustment method for multiple testing to calculate adjusted $P$ values. We considered probe sets to be differentially expressed if the expression levels changed more than twofold $\left(\log _{2}\right.$ fold change $\left.=1\right)$ and the adjusted $P$ value was below 0.05 . Hierarchical clustering with average linkage was carried out using the "1-Pearson correlation" dissimilarity metric. Probe sets for bacterial open reading frames, bacterial sRNAs, and plant genes were analyzed separately. All microarray data in this study were deposited in the NCBI Gene Expression Omnibus database (Edgar et al. 2002) under accession number GSE53705.

\section{qRT-PCR.}

To validate microarray results, cDNA was prepared from the same RNA templates used for RNA amplification and microarray analysis, as described previously (Barnett et al. 2004). qRT-PCR was performed using a C1000 Thermal Cycler equipped with a CFX96 Real-Time system (Bio-Rad) and the DyNAmo Flash SYBR green qPCR kit (Thermo Fisher Scientific). PCR reactions for each of the three biological replicates were performed in technical triplicate. A total of $3 \mathrm{ng}$ of cDNA and 10 pmol primer (sequences are available upon request) were used for each $20-\mu \mathrm{l}$ reaction reaction. The PCR program was $95^{\circ} \mathrm{C}$ for $5 \mathrm{~min}$, followed by 40 cycles of $95^{\circ} \mathrm{C}$ for $10 \mathrm{~s}, 60^{\circ} \mathrm{C}$ for $20 \mathrm{~s}, 72^{\circ} \mathrm{C}$ for $30 \mathrm{~s}$, and $76^{\circ} \mathrm{C}$ for $10 \mathrm{~s}$, during which the fluorescence was recorded. After a final extension step of $72^{\circ} \mathrm{C}$ for $1 \mathrm{~min}$, a dissociation curve from 60 to $95^{\circ} \mathrm{C}$ was recorded to confirm the specificity of the amplification. Data were analyzed using CFX manager software (Bio-Rad) and normalized with the $2^{-\Delta \Delta \mathrm{C}(\mathrm{t})}$ method (Livak and Schmittgen 2001). The variance and average of the microarray intensity values for each bacterial gene in all plant mutant samples were calculated to select an appropriate reference gene. From a list of the ten bacterial genes with the lowest signal variance, $n u o L$ was chosen as an internal control gene.

\section{Comparison with previous transcriptome experiments.}

We compared our microarray results with the data of 28 previous studies investigating $S$. meliloti gene expression in root nodules, during growth on various nutrients, during adaptations to different environmental conditions, after exposure to different stresses, and after deletion of certain genes. From these previous studies, we defined 125 gene sets. Each gene set consisted either of a previously identified gene cluster of coregulated genes or of genes that were found to be increased or decreased by a treatment during earlier studies. To compare our results with earlier studies that used different microarray platforms, we included only genes that are shared in common between our Symbiosis Chip and the platform used in the previous study, e.g., if we compare our data with those of Becker et al. (2004), we only consider those 6,103 genes that can be detected by our Symbiosis Chip and the Sm6Koligo chip that was used by Becker et al. (2004). We used two methods for gene-set enrichment analysis. First, we calculated if genes belonging to a gene set from a previous experiment are over- or underrepresented in the $d n f$ mutants in comparison with the wild-type (Jemalong) using PGSEA (PGSEA software). We used the PGSEA and LIMMA (Smyth 2005) R packages as described in the PGSEA documentation to determine $\log _{2}$ fold changes and $P$ values for each functional group found in the genome. Second, we tested whether a gene set from a previous experiment is significantly enriched in bacterial gene clusters. We calculated the $P$ value for the case of finding the same or higher numbers of genes belonging to a functional group within a cluster, using Fisher's exact test, which is implemented in $\mathrm{R}$ with the "fisher.test" function.

\section{Functional enrichment analysis.}

To study if functional bacterial gene categories are enriched among the differentially expressed genes, we carried out functional enrichment analysis based on the Riley functional classification system and the annotation at the $S$. meliloti genome browser. For analysis of plant gene expression, we used the MapMan functional classification system (Mt_Mt3.5_0411 MapMan bins). To analyze whether a certain functional category is either positively or negatively enriched in nodules from $d n f$ mutants, we calculated $P$ values and $\log _{2}$-fold changes using PGSEA and LIMMA (Smyth 2005) R packages. We used Fisher's exact test, as described for the enrichment analysis of functional categories, to identify if a functional group is overrepresented in plant or bacterial gene clusters.

\section{ACKNOWLEDGMENTS}

This work was supported by National Institutes of Health grant GM093628 to S. R. Long and a German Academic Exchange Services Postdoctoral Scholarship to C. Lang. We thank M. J. Barnett, R. F. Fisher, and $\mathrm{H}$. Ichida for critically reading the manuscript.

\section{LITERATURE CITED}

Barnett, M. J., Bittner, A. N., Toman, C. J., Oke, V., and Long, S. R. 2012. Dual RpoH sigma factors and transcriptional plasticity in a symbiotic bacterium. J. Bacteriol. 194:4983-4994.

Barnett, M. J., Toman, C. J., Fisher, R. F., and Long, S. R. 2004. A dualgenome Symbiosis Chip for coordinate study of signal exchange and development in a prokaryote-host interaction. Proc. Natl. Acad. Sci. U.S.A. 101:16636-16641.

Batut, J., Daveran-Mingot, M. L., David, M., Jacobs, J., Garnerone, A. M., and Kahn, D. 1989. fixK, a gene homologous with fnr and crp from Escherichia coli, regulates nitrogen fixation genes both positively and negatively in Rhizobium meliloti. EMBO (Eur. Mol. Biol. Organ.) J. 8: 1279-1286.

Becana, M., Matamoros, M. A., Udvardi, M., and Dalton, D. A. 2010. Recent insights into antioxidant defenses of legume root nodules. New Phytol. 188:960-976

Becker, A., Bergès, H., Krol, E., Bruand, C., Rüberg, S., Capela, D., Lauber, E., Meilhoc, E., Ampe, F., de Bruijn, F. J., Fourment, J., Francez-Charlot, A., Kahn, D., Küster, H., Liebe, C., Pühler, A., Weidner, S., and Batut, J. 2004. Global changes in gene expression in Sinorhizobium meliloti 1021 under microoxic and symbiotic conditions. Mol. Plant-Microbe Interact. 17:292-303.

Benjamini, Y., and Hochberg, Y. 1995. Controlling the false discovery rate: A practical and powerful approach to multiple testing. J Roy. Stat. Soc. B Met. 57:289-300.

Bobik, C., Meilhoc, E., and Batut, J. 2006. FixJ: A major regulator of the oxygen limitation response and late symbiotic functions of Sinorhizobium meliloti. J. Bacteriol. 188:4890-4902.

Bourcy, M., Brocard, L., Pislariu, C. I., Cosson, V., Mergaert, P., Tadege, M., Mysore, K. S., Udvardi, M. K., Gourion, B., and Ratet, P. 2013. Medicago truncatula DNF2 is a PI-PLC-XD-containing protein required for bacteroid persistence and prevention of nodule early senescence and defense-like reactions. New Phytol. 197:1250-1261.

Capela, D., Filipe, C., Bobik, C., Batut, J., and Bruand, C. 2006 Sinorhizobium meliloti differentiation during symbiosis with alfalfa: A transcriptomic dissection. Mol. Plant-Microbe Interact. 19:363-372.

Cárdenas, L., Martínez, A., Sánchez, F., and Quinto, C. 2008. Fast, transient and specific intracellular ROS changes in living root hair cells responding to Nod factors (NFs). Plant J. 56:802-813. 
Chen, E. J., Fisher, R. F., Perovich, V. M., Sabio, E. A., and Long, S. R. 2009. Identification of direct transcriptional target genes of ExoS/ChvI twocomponent signaling in Sinorhizobium meliloti. J. Bacteriol. 191:6833-6842.

Cheng, H. P., and Walker, G. C. 1998. Succinoglycan is required for initiation and elongation of infection threads during nodulation of alfalfa by Rhizobium meliloti. J. Bacteriol. 180:5183-5191.

Damiani, I., Baldacci-Cresp, F., Hopkins, J., Andrio, E., Balzergue, S., Lecomte, P., Puppo, A., Abad, P., Favery, B., and Hérouart, D. 2012. Plant genes involved in harbouring symbiotic rhizobia or pathogenic nematodes. New Phytol. 194:511-522.

David, M., Daveran, M. L., Batut, J., Dedieu, A., Domergue, O., Ghai, J., Hertig, C., Boistard, P., and Kahn, D. 1988. Cascade regulation of nif gene expression in Rhizobium meliloti. Cell 54:671-683.

Davies, B. W., and Walker, G. C. 2007. Disruption of sitA compromises Sinorhizobium meliloti for manganese uptake required for protection against oxidative stress. J. Bacteriol. 189:2101-2109.

de Lucena, D. K. C., Pühler, A., and Weidner, S. 2010. The role of sigma factor $\mathrm{RpoH} 1$ in the $\mathrm{pH}$ stress response of Sinorhizobium meliloti. BMC Microbiol. 10:265.

De Nisco, N. J., Abo, R. P., Wu, C. M., Penterman, J., and Walker, G. C. 2014. Global analysis of cell cycle gene expression of the legume symbiont Sinorhizobium meliloti. Proc. Natl. Acad. Sci. U.S.A. 111: 3217-3224.

del Val, C., Rivas, E., Torres-Quesada, O., Toro, N., and Jiménez-Zurdo, J. I. 2007. Identification of differentially expressed small non-coding RNAs in the legume endosymbiont Sinorhizobium meliloti by comparative genomics. Mol. Microbiol. 66:1080-1091.

Domínguez-Ferreras, A., Pérez-Arnedo, R., Becker, A., Olivares, J., Soto, M. J., and Sanjuán, J. 2006. Transcriptome profiling reveals the importance of plasmid pSymB for osmoadaptation of Sinorhizobium meliloti. J. Bacteriol. 188:7617-7625.

Domonkos, A., Horvath, B., Marsh, J. F., Halasz, G., Ayaydin, F., Oldroyd, G. E. D., and Kalo, P. 2013. The identification of novel loci required for appropriate nodule development in Medicago truncatula. BMC Plant Biol. 13:157.

Downie, J. A. 2010. The roles of extracellular proteins, polysaccharides and signals in the interactions of rhizobia with legume roots. FEMS Microbiol. Rev. 34:150-170.

Edgar, R., Domrachev, M., and Lash, A. E. 2002. Gene Expression Omnibus: NCBI gene expression and hybridization array data repository. Nucleic Acids Res. 30:207-210.

Ehrhardt, D. W., Atkinson, E. M., and Long, S. R. 1992. Depolarization of alfalfa root hair membrane potential by Rhizobium meliloti Nod factors. Science 256:998-1000.

Fields, A. T., Navarrete, C. S., Zare, A. Z., Huang, Z., Mostafavi, M., Lewis, J. C., Rezaeihaghighi, Y., Brezler, B. J., Ray, S., Rizzacasa, A. L., Barnett, M. J., Long, S. R., Chen, E. J., and Chen, J. C. 2012. The conserved polarity factor podJ1 impacts multiple cell envelope-associated functions in Sinorhizobium meliloti. Mol. Microbiol. 84:892-920.

Gentleman, R. C., Carey, V. J., Bates, D. M., Bolstad, B., Dettling, M., Dudoit, S., Ellis, B., Gautier, L., Ge, Y., Gentry, J., Hornik, K., Hothorn, T., Huber, W., Iacus, S., Irizarry, R., Leisch, F., Li, C., Maechler, M., Rossini, A. J., Sawitzki, G., Smith, C., Smyth, G., Tierney, L., Yang, J. Y. H., and Zhang, J. 2004. Bioconductor: Open software development for computational biology and bioinformatics. Genome Biol. 5:R80.

Gibson, K. E., Barnett, M. J., Toman, C. J., Long, S. R., and Walker, G. C. 2007. The symbiosis regulator CbrA modulates a complex regulatory network affecting the flagellar apparatus and cell envelope proteins. J. Bacteriol. 189:3591-3602.

Gibson, K. E., Kobayashi, H., and Walker, G. C. 2008. Molecular determinants of a symbiotic chronic infection. Annu. Rev. Genet. 42:413-441.

Griffitts, J. S., Carlyon, R. E., Erickson, J. H., Moulton, J. L., Barnett, M. J., Toman, C. J., and Long, S. R. 2008. A Sinorhizobium meliloti osmosensory two-component system required for cyclic glucan export and symbiosis. Mol. Microbiol. 69:479-490.

Hellweg, C., Pühler, A., and Weidner, S. 2009. The time course of the transcriptomic response of Sinorhizobium meliloti 1021 following a shift to acidic $\mathrm{pH}$. BMC Microbiol. 9:37.

Irizarry, R. A., Hobbs, B., Collin, F., Beazer-Barclay, Y. D., Antonellis, K. J., Scherf, U., and Speed, T. P. 2003. Exploration, normalization, and summaries of high density oligonucleotide array probe level data. Biostatistics 4:249-264.

Jamet, A., Mandon, K., Puppo, A., and Hérouart, D. 2007. $\mathrm{H}_{2} \mathrm{O}_{2}$ is required for optimal establishment of the Medicago sativa/Sinorhizobium meliloti symbiosis. J. Bacteriol. 189:8741-8745.

Jones, K. M., Kobayashi, H., Davies, B. W., Taga, M. E., and Walker, G. C. 2007. How rhizobial symbionts invade plants: The SinorhizobiumMedicago model. Nat. Rev. Microbiol. 5:619-633.
Kannenberg, E. L., and Carlson, R. W. 2001. Lipid A and O-chain modifications cause Rhizobium lipopolysaccharides to become hydrophobic during bacteroid development. Mol. Microbiol. 39:379-391.

Kersey, P. J., Allen, J. E., Christensen, M., Davis, P., Falin, L. J., Grabmueller, C., Hughes, D. S. T., Humphrey, J., Kerhornou, A., Khobova, J., Langridge, N., McDowall, M. D., Maheswari, U., Maslen, G., Nuhn, M., Ong, C. K., Paulini, M., Pedro, H., Toneva, I., Tuli, M. A., Walts, B., Williams, G., Wilson, D., Youens-Clark, K. Monaco, M. K., Stein, J., Wei, X., Ware, D., Bolser, D. M., Howe, K. L., Kulesha, E., Lawson, D., and Staines, D. M. 2014. Ensembl Genomes 2013: Scaling up access to genome-wide data. Nucleic Acids Res. 42:D546-D552.

Kondorosi, E., Mergaert, P., and Kereszt, A. 2013. A paradigm for endosymbiotic life: Cell differentiation of Rhizobium bacteria provoked by host plant factors. Annu. Rev. Microbiol. 67:611-628.

Krol, E., and Becker, A. 2011. ppGpp in Sinorhizobium meliloti: Biosynthesis in response to sudden nutritional downshifts and modulation of the transcriptome. Mol. Microbiol. 81:1233-1254.

Limpens, E., Moling, S., Hooiveld, G., Pereira, P. A., Bisseling, T., Becker, J. D., and Küster, H. 2013. Cell- and tissue-specific transcriptome analyses of Medicago truncatula root nodules. PLoS ONE 8:e64377.

Livak, K. J., and Schmittgen, T. D. 2001. Analysis of relative gene expression data using real-time quantitative PCR and the $\left.2^{(-\Delta \Delta \mathrm{C}(\mathrm{T})}\right)$ Method Methods 25:402-408.

Matamoros, M. A., Dalton, D. A., Ramos, J., Clemente, M. R., Rubio, M. C., and Becana, M. 2003. Biochemistry and molecular biology of antioxidants in the rhizobia-legume symbiosis. Plant Physiol. 133: 499-509.

Maunoury, N., Redondo-Nieto, M., Bourcy, M., Van de Velde, W., Alunni, B., Laporte, P., Durand, P., Agier, N., Marisa, L., Vaubert, D., Delacroix H., Duc, G., Ratet, P., Aggerbeck, L., Kondorosi, E., and Mergaert, P. 2010. Differentiation of symbiotic cells and endosymbionts in Medicago truncatula nodulation are coupled to two transcriptome-switches. PLoS ONE 5:e9519.

Meilhoc, E., Cam, Y., Skapski, A., and Bruand, C. 2010. The response to nitric oxide of the nitrogen-fixing symbiont Sinorhizobium meliloti. Mol. Plant-Microbe Interact. 23:748-759.

Mergaert, P., Uchiumi, T., Alunni, B., Evanno, G., Cheron, A., Catrice, O. Mausset, A. E., Barloy-Hubler, F., Galibert, F., Kondorosi, A., and Kondorosi, E. 2006. Eukaryotic control on bacterial cell cycle and differentiation in the Rhizobium-legume symbiosis. Proc. Natl. Acad. Sci. U.S.A. 103:5230-5235.

Mitra, R. M., and Long, S. R. 2004. Plant and bacterial symbiotic mutants define three transcriptionally distinct stages in the development of the Medicago truncatula/Sinorhizobium meliloti symbiosis. Plant Physiol 134:595-604

Mitra, R. M., Shaw, S. L., and Long, S. R. 2004. Six nonnodulating plant mutants defective for Nod factor-induced transcriptional changes associated with the legume-rhizobia symbiosis. Proc. Natl. Acad. Sci. U.S.A. 101:10217-10222.

Mitsui, H., Sato, T., Sato, Y., Ito, N., and Minamisawa, K. 2004 Sinorhizobium meliloti RpoH1 is required for effective nitrogen-fixing symbiosis with alfalfa. Mol. Genet. Genomics 271:416-425

Moreau, S., Verdenaud, M., Ott, T., Letort, S., de Billy, F., Niebel, A. Gouzy, J., de Carvalho-Niebel, F., and Gamas, P. 2011. Transcription reprogramming during root nodule development in Medicago truncatula. PLoS ONE 6:e16463.

Oke, V., Rushing, B. G., Fisher, E. J., Moghadam-Tabrizi, M., and Long, S. R. 2001. Identification of the heat-shock sigma factor $\mathrm{RpoH}$ and a second RpoH-like protein in Sinorhizobium meliloti. Microbiology 147:2399-2408.

Ott, T., Sullivan, J., James, E. K., Flemetakis, E., Günther, C., Gibon, Y., Ronson, C., and Udvardi, M. 2009. Absence of symbiotic leghemoglobins alters bacteroid and plant cell differentiation during development of Lotus japonicus root nodules. Mol. Plant-Microbe Interact. 22: 800-808.

Ott, T., van Dongen, J. T., Günther, C., Krusell, L., Desbrosses, G., Vigeolas, H., Bock, V., Czechowski, T., Geigenberger, P., and Udvardi, M. K. 2005. Symbiotic leghemoglobins are crucial for nitrogen fixation in legume root nodules but not for general plant growth and development. Curr. Biol. 15:531-535.

Pellock, B. J., Cheng, H. P., and Walker, G. C. 2000. Alfalfa root nodule invasion efficiency is dependent on Sinorhizobium meliloti polysaccharides. J. Bacteriol. 182:4310-4318.

Penterman, J., Abo, R. P., De Nisco, N. J., Arnold, M. F. F., Longhi, R., Zanda, M., and Walker, G. C. 2014. Host plant peptides elicit a transcriptional response to control the Sinorhizobium meliloti cell cycle during symbiosis. Proc. Natl. Acad. Sci. U.S.A. 111:3561-3566. 
Peters, N. K., and Long, S. R. 1988. Alfalfa root exudates and compounds which promote or inhibit induction of Rhizobium meliloti nodulation genes. Plant Physiol. 88:396-400.

Pislariu, C. I., and Dickstein, R. 2007. An IRE-like AGC kinase gene, MtIRE, has unique expression in the invasion zone of developing root nodules in Medicago truncatula. Plant Physiol. 144:682-694.

Riley, M. 1993. Functions of the gene products of Escherichia coli. Microbiol. Rev. 57:862-952.

Rossbach, S., Mai, D. J., Carter, E. L., Sauviac, L., Capela, D., Bruand, C., and de Bruijn, F. J. 2008. Response of Sinorhizobium meliloti to elevated concentrations of cadmium and zinc. Appl. Environ. Microbiol. 74: 4218-4221.

Roux, B., Rodde, N., Jardinaud, M.-F., Timmers, T., Sauviac, L., Cottret, L., Carrère, S., Sallet, E., Courcelle, E., Moreau, S., Debellé, F., Capela, D., de Carvalho-Niebel, F., Gouzy, J., Bruand, C., and Gamas, P. 2014. An integrated analysis of plant and bacterial gene expression in symbiotic root nodules using laser-capture microdissection coupled to RNA sequencing. Plant J. 77:817-837.

Sauviac, L., Philippe, H., Phok, K., and Bruand, C. 2007. An extracytoplasmic function sigma factor acts as a general stress response regulator in Sinorhizobium meliloti. J. Bacteriol. 189:4204-4216.

Schlüter, J. P., Reinkensmeier, J., Barnett, M. J., Lang, C., Krol, E., Giegerich, R., Long, S. R., and Becker, A. 2013. Global mapping of transcription start sites and promoter motifs in the symbiotic $\alpha$-proteobacterium Sinorhizobium meliloti 1021. BMC Genomics 14:156.

Schlüter, J.-P., Reinkensmeier, J., Daschkey, S., Evguenieva-Hackenberg, E., Janssen, S., Jänicke, S., Becker, J. D., Giegerich, R., and Becker, A. 2010. A genome-wide survey of sRNAs in the symbiotic nitrogen-fixing alpha-proteobacterium Sinorhizobium meliloti. BMC Genomics 11:245.

Serres, M. H., and Riley, M. 2000. MultiFun, a multifunctional classification scheme for Escherichia coli K-12 gene products. Microb. Comp. Genomics 5:205-222.

Smyth, G. K. 2005. Limma: Linear models for microarray data. Pages 397-420. in: Bioinformatics and Computational Biology Solutions Using R and Bioconductor. R. Gentleman, V. Carey, S. Dudoit, R. Irizarry, and W. Huber, eds. Springer, New York.

Soupène, E., Foussard, M., Boistard, P., Truchet, G., and Batut, J. 1995. Oxygen as a key developmental regulator of Rhizobium meliloti $\mathrm{N}_{2}$-fixation gene expression within the alfalfa root nodule. Proc. Natl. Acad. Sci. U.S.A. 92:3759-3763.

Stafford, H. A. 1997. Roles of flavonoids in symbiotic and defense functions in legume roots. Bot. Rev. 63:27-39.

Starker, C. G., Parra-Colmenares, A. L., Smith, L., Mitra, R. M., and Long, S. R. 2006. Nitrogen fixation mutants of Medicago truncatula fail to support plant and bacterial symbiotic gene expression. Plant Physiol. 140:671-680.

Tiricz, H., Szűcs, A., Farkas, A., Pap, B., Lima, R. M., Maróti, G., Kondorosi, É., and Kereszt, A. 2013. Antimicrobial nodule-specific cysteine-rich peptides induce membrane depolarization-associated changes in the transcriptome of Sinorhizobium meliloti. Appl. Environ. Microbiol. 79:6737-6746.

Udvardi, M., and Poole, P. S. 2013. Transport and metabolism in legumerhizobia symbioses. Annu. Rev. Plant Biol. 64:781-805.

Van de Velde, W., Guerra, J. C., De Keyser, A., De Rycke, R., Rombauts, S., Maunoury, N., Mergaert, P., Kondorosi, E., Holsters, M., and Goormachtig, S. 2006. Aging in legume symbiosis. A molecular view on nodule senescence in Medicago truncatula. Plant Physiol. 141: 711-720.

Van de Velde, W., Zehirov, G., Szatmari, A., Debreczeny, M., Ishihara, H., Kevei, Z., Farkas, A., Mikulass, K., Nagy, A., Tiricz, H., SatiatJeunemaître, B., Alunni, B., Bourge, M., Kucho, K., Abe, M., Kereszt, A., Maroti, G., Uchiumi, T., Kondorosi, E., and Mergaert, P. 2010. Plant peptides govern terminal differentiation of bacteria in symbiosis. Science 327:1122-1126.

Vance, C. P. 2001. Symbiotic nitrogen fixation and phosphorus acquisition. Plant nutrition in a world of declining renewable resources. Plant Physiol. 127:390-397.

Vasse, J., de Billy, F., Camut, S., and Truchet, G. 1990. Correlation between ultrastructural differentiation of bacteroids and nitrogen fixation in alfalfa nodules. J. Bacteriol. 172:4295-4306.

Wang, D., Griffitts, J., Starker, C., Fedorova, E., Limpens, E., Ivanov, S., Bisseling, T., and Long, S. 2010. A nodule-specific protein secretory pathway required for nitrogen-fixing symbiosis. Science 327:1126-1129.

Wells, D. H., Chen, E. J., Fisher, R. F., and Long, S. R. 2007. ExoR is genetically coupled to the ExoS-ChvI two-component system and located in the periplasm of Sinorhizobium meliloti. Mol. Microbiol. 64: 647-664.

Xiao, T. T., Schilderink, S., Moling, S., Deinum, E. E., Kondorosi, E., Franssen, H., Kulikova, O., Niebel, A., and Bisseling, T. 2014. Fate map of Medicago truncatula root nodules. Development 141:3517-3528.

Young, N. D., Debellé, F., Oldroyd, G. E. D., Geurts, R., Cannon, S. B., Udvardi, M. K., Benedito, V. A., Mayer, K. F. X., Gouzy, J., Schoof, H., Van de Peer, Y., Proost, S., Cook, D. R., Meyers, B. C., Spannagl, M., Cheung, F., De Mita, S., Krishnakumar, V., Gundlach, H., Zhou, S., Mudge, J., Bharti, A. K., Murray, J. D., Naoumkina, M. A., Rosen, B., Silverstein, K. A. T., Tang, H., Rombauts, S., Zhao, P. X., Zhou, P., Barbe, V., Bardou, P., Bechner, M., Bellec, A., Berger, A., Bergès, H., Bidwell, S., Bisseling, T., Choisne, N., Couloux, A., Denny, R., Deshpande, S., Dai, X., Doyle, J. J., Dudez, A. M., Farmer, A. D., Fouteau, S., Franken, C., Gibelin, C., Gish, J., Goldstein, S., González, A. J., Green, P. J., Hallab, A., Hartog, M., Hua, A., Humphray, S. J., Jeong, D. H., Jing, Y., Jöcker, A., Kenton, S. M., Kim, D. J., Klee, K., Lai, H., Lang, C., Lin, S., Macmil, S. L., Magdelenat, G., Matthews, L., McCorrison, J., Monaghan, E. L., Mun, J. H., Najar, F. Z., Nicholson, C., Noirot, C., O’Bleness, M., Paule, C. R., Poulain, J., Prion, F., Qin, B., Qu, C., Retzel, E. F., Riddle, C., Sallet, E., Samain, S., Samson, N., Sanders, I., Saurat, O., Scarpelli, C., Schiex, T., Segurens, B., Severin, A. J., Sherrier, D. J., Shi, R., Sims, S., Singer, S. R., Sinharoy, S., Sterck, L., Viollet, A., Wang, B. B., Wang, K., Wang, M., Wang, X., Warfsmann, J., Weissenbach, J., White, D. D., White, J. D., Wiley, G. B., Wincker, P., Xing, Y., Yang, L., Yao, Z., Ying, F., Zhai, J., Zhou, L., Zuber, A., Dénarié, J., Dixon, R. A., May, G. D., Schwartz, D. C., Rogers, J., Quétier, F., Town, C. D., and Roe, B. A. 2011. The Medicago genome provides insight into the evolution of rhizobial symbioses. Nature 480: 520-524.

\section{AUTHOR-RECOMMENDED INTERNET RESOURCES}

MapMen Site of Analysis database: http://MapMan.gabipd.org/web/guest/MapManstore

PGSEA software: http://www.bioconductor.org/packages/release/bioc/html/PGSEA.html 